\title{
Employment adjustment in German firms
}

\author{
Sven Jung
}

Published online: 31 January 2014

(C) Institut für Arbeitsmarkt- und Berufsforschung 2014

\begin{abstract}
Using a representative establishment data set for Germany, I show that, in line with the existing literature for several countries, firms' adjustment costs for employment are characterized by a fixed and convex functional form. Furthermore, they are asymmetric with dismissal costs exceeding hiring costs. An analysis of firms' adjustment in the period 1996-2010 also indicates that adjustment behavior has changed over time. Comparing the employment adjustment in the two observed business cycles comprising the years 1996-2003 and 2004-2010, I find that the adjustment speed was higher in the second business cycle indicating that adjustment costs have fallen in recent years.
\end{abstract}

Keywords Adjustment costs - Dynamic labor demand . Employment adjustment · Germany

JEL Classification C24 · D22 - E24 · J23

\section{Betriebliche Beschäftigungsanpassung in Deutschland}

Zusammenfassung Anhand von repräsentativen Daten des IAB-Betriebspanels wird gezeigt, dass die Kosten der betrieblichen Beschäftigungsanpassung in Deutschland eine

The author would like to thank Martina Eschelbach, Boris Hirsch, Claus Schnabel, Michael Zibrowius, two anonymous referees as well as participants at the IAB Establishment Panel Survey Conference, the 5th Ph.D. workshop of the Institute of Employment Research, the 6th RGS Doctoral Conference, the 2013 Annual Conference of the Royal Economic Society and the 2013 Annual Conference of the Verein für Socialpolitik for helpful comments and suggestions. The usual disclaimer applies.

S. Jung $(\varangle)$

Lehrstuhl für Arbeitsmarkt- und Regionalpolitik, Friedrich-Alexander-Universität Erlangen-Nürnberg, Lange Gasse 20, 90403 Nürnberg, Germany

e-mail: sven.jung@fau.de funktionale Form mit fixer und konvexer Komponente aufweisen, wie es auch frühere Studien für andere Länder feststellen. Des Weiteren ist die Struktur der Anpassungskosten asymmetrisch, wobei die Entlassungskosten größer als die Einstellungskosten sind. Bei der Analyse des betrieblichen Anpassungsverhaltens für den Zeitraum 1996-2010 wird zudem deutlich, dass sich das Verhalten über die Zeit geändert hat. Ein Vergleich der betrieblichen Beschäftigungsanpassung in den zwei beobachteten Konjunkturzyklen 19962003 und 2004-2010 zeigt eine schnellere Anpassung im zweiten Konjunkturzyklus, was auf gesunkene Anpassungskosten hinweist.

\section{Introduction}

Following the 2008/2009 economic crisis, the adjustment of firms' labor volume has again moved into the focus of economic analysis. Across countries, firms have shown different reactions to this crisis, but also within countries firms' behavior has differed from previous reactions. For example, German firms predominantly adjusted working hours, while less adjustment of the number of employees was visible (see Burda and Hunt 2011). This points to a fundamental change in firms' adjustment processes. Several studies for Germany indicate that firms' employment adjustment has indeed changed over time (see, e.g., Gartner and Klinger 2010; Herzog-Stein and Seifert 2010). However, these studies are mostly based on descriptive analyses of aggregated data. In contrast, the present study provides a more detailed econometric analysis based on data at the establishment level. Using a representative panel data set on German establishments, I estimate a dynamic labor demand model for the period 1996 to 2010. This allows us to compare employment adjustment in the two business cycles occurring 
between 1996 and 2010 and to investigate econometrically whether firms' adjustment behavior has changed over time. Moreover, I analyze labor demand separately for Western and Eastern Germany, thus extending the sparse empirical evidence on dynamic labor demand in Eastern Germany.

I also provide new insights concerning the functional form of firms' adjustment costs. Adjustment costs are an important component of dynamic labor demand theory. Firms' adjustment behavior depends on the functional form of the adjustment costs they face. Although empirical evidence so far indicates a fixed and convex specification (see Vermeulen 2006, p. 11), this has not been established for Germany yet. In the only studies for (Western) Germany which contain an intensive analysis of the functional form, Kölling (1998) prefers a convex and Yaman (2011) a linear functional form of adjustment costs, making the empirical evidence for Germany ambiguous. I will use a different switching regression approach than Kölling (1998) and will show that for Germany in addition to the convex specification a fixed component of adjustment costs is also relevant. Thus, I provide empirical support for the assumption of fixed and convex adjustment costs in Germany. Furthermore, the existing studies do not contain separate results for Western and Eastern Germany, which I provide.

The paper proceeds as follows: Sect. 2 sketches the main aspects of adjustment costs and presents the relevant empirical evidence on the functional form of adjustment costs. Section 3 provides a description of our data. Section 4 shows the empirical model, while Sect. 5 presents and discusses the results of a basic dynamic labor demand model. I investigate the change of firms' adjustment behavior over time in Sect. 6, and Sect. 7 concludes.

\section{Adjustment costs: theoretical considerations and empirical evidence}

The underlying theory for our analysis is the dynamic labor demand theory. While the static labor demand theory focuses on firms' optimal employment level, the dynamic counterpart analyzes firms' adjustment toward the optimum and the time it takes to reach the optimal employment level which is not possible within the static theory (see Cahuc and Zylberberg 2004, p. 212). Adjustment costs are an essential component of dynamic labor demand theory because they play an important role in firms' adjustment behavior. These costs are the reason that a plant does not dismiss all employees before the weekend and re-hire them on Monday (see Franz 2013, p. 146; Nickell 1986, p. 473). Labor is not a completely variable production factor because adjustment costs form a fixed component of total labor costs. Therefore Oi (1962) calls labor a 'quasi-fix' factor. Adjustment costs arise from an employment change and consist of hiring costs (e.g., search, selection, first training, administrative expenses of the Human Resources Department) and costs of dismissals (e.g., severance pay, consideration of dismissal protection, administrative expenses of the Human Resources Department). Ehrenberg and Smith (2012, p. 145) consider hiring costs as investments and so they point out the 'sunk' character of these costs.

Several criteria can be used for distinguishing adjustment costs (see, e.g., Hamermesh 1993a, p. 207; Kölling 1998, p. 8; Nickell 1986, p. 475). Besides internal/external and implicit/explicit, one can distinguish between a gross and a net perspective in the analysis of adjustment costs. Net adjustment costs incur if the number of employees changes. In contrast, each hiring and dismissal decision affects gross adjustment costs, even if the employment level does not change. But there is no clear tendency in previous studies for a certain concept. In this study, I use a net approach due to the underlying empirical model which is based on previous studies using the net approach (see Sect. 4).

The basic theory of dynamic labor demand assumes labor to be a homogeneous production factor, which is a restrictive assumption in the context of adjustment costs (see Kölling 1998, p. 61). Different kinds of jobs and different qualification levels of employees can lead to different sizes of adjustment cost meaning that the firm would not adjust separate groups of employees in the same manner. Yet, following earlier studies, I assume labor to be homogeneous for the sake of analytical simplicity. Nevertheless, this allows us to draw some interesting conclusions about the adjustment procedures of labor demand (see Kölling 1998, p. 61).

Another simplifying assumption concerns the two dimensions of labor demand. Firms can adjust their total labor volume by changing the number of employees and by changing working hours. Adjustment of working time gives more flexibility compared to an adjustment of just the number of employees. It can be done faster (see Sargent 1978, p. 1015) and cheaper (see Shapiro 1986, p. 516) than the adjustment of the number of employees. Therefore, in periods when the adjustment of the number of employees is no longer optimal, a firm can still get closer to the optimal labor volume by changing the number of hours worked (see, e.g., Nickell 1978, pp. 332-335; Santamäki 1988, pp. 101-102). Yet, the consideration of both dimensions leads to complex adjustment models. In order to simplify the model, working hours are ignored in the following analysis. The data set used (see Sect. 3), which does not provide clear information about working hours, is another reason for disregarding the working time. However, basic conclusions about adjustment procedures of labor demand are still possible (see Hamermesh 1993a, p. 209).

Furthermore, adjustment costs differ in functional form. One can classify fixed, linear, and convex adjustment costs. 
Fixed adjustment costs incur from firms' decision to adjust employment independently of the amount of employment adjustment. ${ }^{1}$ An example is a job advertisement for two or four employees, which costs the same in both cases (see Hamermesh 1989, p. 675; Kölling 1998, p. 44). If the firm faces a new optimal employment level due to a shock or a changing economic situation, it must make a decision about an adjustment to the new optimum. Fixed adjustment costs and their relative magnitude to the profits resulting from an employment level closer to the optimal one are essential for this decision. If profits exceed costs, the firm will adjust employment. Because of the fixed specification, firms' adjustment is then done instantly and completely towards the new optimal employment level (see Hamermesh 1993a, p. 214). ${ }^{2}$

Linear adjustment costs, which increase proportionally in the amount of adjustment, result in a different adjustment behavior. Again, firms adjust instantly while taking into account the costs-profits relation. But with a linear structure, the employment level is not adjusted completely towards the optimal level (see, e.g., Kölling 1998, p. 30; Nickell 1986, p. 491). Instead, firms keep employment constant near the optimum because of costs exceeding profits (see, e.g., Anderson 1993, p. 1018; Kölling 1998, p. 30; Nickell 1978, p. 332; Nickell 1986, p. 495). Examples for a linear cost structure, such as hiring from an agency (see Nickell 1986, p. 477) or severance pay, show that linear adjustment costs are not unrealistic.

Convex adjustment costs, mostly used in a quadratic specification, are the third functional form. This specification was the one first used in the literature and goes back to Holt et al. (1960). Convex costs increase disproportionately with the amount of adjustment. Although a convex specification might be suitable for a specific part of adjustment (see Nickell 1986, p. 477), it should not be considered as the only existing functional form (see, e.g., Bentolila and Bertola 1990, p. 382; Hamermesh 1989, p. 475; Nickell 1986, p. 477; Rothschild 1971, p. 605). A convex cost structure is a very restrictive assumption and difficult to justify. The reason for the common use of convex adjustment costs in the literature was the simple analytical handling in the models (see, e.g., Kölling 1998, p. 9; Pfann and Verspagen 1989, p. 365). But already Holt et al. (1960, p. 52) mentioned that the quadratic form is just a '.. suitable first approximation.' Adjustment costs can have different forms in reality (see Nickell 1986, p. 519). Assuming convex adjustment costs rather than fixed or linear costs, firms spread adjustment of employment over several periods (see, e.g.,

\footnotetext{
${ }^{1}$ For details about fix adjustment costs I refer to Hamermesh (1989, 1990).

${ }^{2}$ The result of fixed adjustment costs are periods with adjustment and periods with no adjustment. Therefore Hamermesh (1990, p. 96) calls this behavior 'bang-bang adjustment'.
}

Cahuc and Zylberberg 2004, p. 218; Hamermesh 1993a, p. 211; Nickell 1986, p. 483). Because of the convexity, marginal costs increase with the amount of employment adjustment. Therefore, it is optimal to spread the adjustment over several periods. Furthermore, the optimal employment level will not be reached in finite time (see, e.g., Kölling 1998 , p. 21; Nickell 1986, p. 483), although there is longrun convergence to the optimum (see Kölling 1998, p. 60).

Considering the functional form also raises the question whether adjustment costs are symmetric or asymmetric, thus whether hiring costs and firing costs are equal. A symmetric cost structure simplifies the econometric model but there is no reason to expect an upward employment adjustment to generate the same costs as a downward employment adjustment (see Schiantarelli and Sembenelli 1993, p. 149). Therefore, asymmetric adjustment costs are a much less restrictive assumption. The costs of hiring and firing result from different sources so that asymmetry is a reasonable assumption.

In case of a fixed specification, increasing adjustment costs lead to a longer period with no adjustment and a greater amount of employment change if an adjustment is optimal (see Gorter et al. 2003, p. 100). Assuming a linear structure instead, higher adjustment costs also cause a longer period of inaction. Furthermore, the difference between the optimal employment level and the actual level when the firm stops adjustment is larger (see, e.g., Anderson 1993, p. 1018; Nickell 1978, p. 337; Nickell 1986, p. 495). Finally, the result of higher convex adjustment costs is a slower adjustment which is spread over many more periods (see, e.g., Cahuc and Zylberberg 2004, p. 218; Sargent 1978, p. 1018).

There is a large body of empirical evidence on the significant role of firms' adjustment costs (see, e.g., Burgess 1988; Dolfin 2006, p. 870; Gavosto and Sestito 1993, p. 447; Nissim 1984, p. 433; Oi 1962; Rosen 1968, p. 337; Rota 2004, p. 43) showing that these costs actually have an effect on adjustment behavior. In contrast, Hall (2004) as well as Pindyck and Rotemberg (1983a, 1983b) find that adjustment costs are just marginal. Regarding the functional form, the studies by Holt et al. (1960) and Nickell (1984, p. 546) show that a convex structure is appropriate. ${ }^{3}$ However, their evidence it not entirely persuasive as they assume pure convexity in their empirical models and make no comparison with other functional forms in these analyses. In addition, given the not convincing theoretical justification it is not surprising that there are many empirical objections to pure convex costs.

Hamermesh (1989, p. 687) presents first evidence against a pure convex structure. He shows that a fixed cost specification suits the data better than convex adjustment costs. The results of Anderson (1993), Caballero et al. (1997), Cooper

\footnotetext{
${ }^{3}$ Nickell (1984, p. 546) finds that the adjustment has a lag, which is just the case in the presence of convex adjustment costs.
} 
and Willis (2009), Gavosto and Sestito (1993), Holtz-Eakin and Rosen (1991), Rota (2004), and Varejão and Portugal (2007a) are also inconsistent with the assumption of pure convex adjustment costs. Instead, they find that firms' adjustment behavior is better represented by an assumption of a combination of various functional forms, for example, a fixed and convex specification (see, e.g., Abowd and Kramarz 2003; Cooper et al. 2004; Hamermesh 1992; Kramarz and Michaud 2010; Lapatinas 2009; Nilsen et al. 2007; Pfann and Verspagen 1989). ${ }^{4}$ For Germany, however, the studies by Kölling (1998) and Yaman (2011), which are the only two analyses investigating intensively the functional form of the adjustment costs I am aware of, find that a model with combined fixed and convex adjustment costs components provides no further insights compared with a pure convex specification (see Kölling 1998, p. 153) or respectively that a model with linear adjustment costs fits better the data (see Yaman 2011, p. 25). ${ }^{5}$ Therefore, the predominance of the combination structure for adjustment cost has not been shown to extend to Germany yet.

Regarding the symmetry or rather asymmetry of adjustment costs the empirical evidence clearly favors asymmetry. However, there is no clarity concerning the relation of hiring costs to dismissal costs (see Hunt 2000, p. 181). Based on data from the production sector in Italy, Jaramillo et al. (1993) find higher dismissal costs compared to hiring costs. This relation also has been confirmed for Germany (see Burda 1991, p. 73; Kölling 1998, p. 151), for France (see Abowd and Kramarz 2003; Goux et al. 2001; Kramarz and Michaud 2010) as well as for Norway (see Nilsen et al. 2007, p. 597). In addition, based upon British and Dutch data, Pfann and Palm (1993) show higher dismissal costs for non-production workers, whereas they find higher hiring costs for production workers. Other evidence for hiring costs exceeding dismissal costs is described in Pfann and Verspagen (1989) for the Netherlands and in Chang and Stefanou (1988), Hamermesh (1993a, p. 208) as well as in Hamermesh and Pfann (1996) for the US.

Our study investigates firms' adjustment behavior of labor in Germany. I assume a combined cost structure and asymmetry with dismissal costs exceeding hiring costs that I will test in the following analysis. Our hypothesis regarding the relation of hiring and dismissal costs is based on the labor market institutions in Germany. Germany, like other countries in continental Europe, has a more regulated labor market with higher dismissal protection than, for instance,

\footnotetext{
${ }^{4}$ Vermeulen (2006, p. 11) confirms the dominance of a combination structure for adjustment costs in the existing literature, while only some of these studies use dynamic labor demand models for the analysis.

${ }^{5}$ Muehlemann and Pfeifer (2013) also provide results for the functional form of adjustment costs in Germany, but their analysis focusses on hiring costs of skilled workers. They find a convex structure for these costs.
}

the US (see, e.g., Abraham and Houseman 1994, p. 59; Burda 1991, p. 62; Emerson 1988, p. 776). This in turn leads to less flexibility for firms and results in higher adjustment costs, especially higher dismissal costs in Europe compared to the US (see, e.g., Hunt 2000, p. 177; Merkl and Wesselbaum 2011, p. 805).

\section{Data and descriptive evidence}

The data used for the analysis come from the IAB Establishment Panel, which is a representative annual survey of German establishments. ${ }^{6}$ The establishments interviewed are drawn from a stratified sample of plants, which are included in the German employment statistics. The strata are defined over plant sizes and industries; however, sampling within each cell is random. The panel oversamples large establishments, but weighting for representative results is possible. The panel started in 1993 with Western German plants and was extended to Eastern German plants in 1996. Nowadays, almost 16,000 establishments are interviewed each year. Information about, for example, plant characteristics, wages, profitability, management policy and especially about the workforce composition and its development over time is provided by the panel with the reference date June 30th.

I use the waves 1996 until 2010. It is important to note that the IAB Establishment Panel is an annual survey. This temporal aggregation makes an analysis of firms' employment adjustment difficult so that one would prefer quarterly or monthly data (see Hamermesh 1993b, pp. 97-106; Kölling 1998, pp. 112-113). When using annual data I implicitly assume that the firms' decision are taken at intervals of one year which is mostly not given in reality (see Hamermesh 1993b, pp. 97-98). Thus, observation time and timing of firms' decision are not the same and results may be biased. Previous studies show that a higher level of temporal aggregation leads to a lower adjustment speed (see, e.g., Hamermesh 1993b, p. 99; Kölling 1998, p. 124; Varejão and Portugal 2007b, p. 13). However, Kölling (1998, p. 113) does not interpret the explanation by Hamermesh (1993b, pp. 97-98) as a theoretical reason for this bias. Furthermore, Varejão and Portugal (2007b, p. 13) also argue that a 'temporal aggregation does not imply a priori any bias'. Moreover, when using quarterly or monthly data seasonal fluctuations could lead to misleading results (see Kölling 1998, p. 113). Therefore, Kölling (1998, p. 113) argues that an analysis of dynamic labor demand using the IAB Establishment Panel is possible if one looks critically at the results. This has to be considered in the analysis.

\footnotetext{
${ }^{6}$ For a detailed description of this data set see Bellmann et al. (2002), Fischer et al. (2009), and Kölling (2000).
} 
Fig. 1 Average number of employees per plant

Notes: Weighted data, private sector only

Source: IAB Establishment

Panel, waves 1996-2010, own calculations

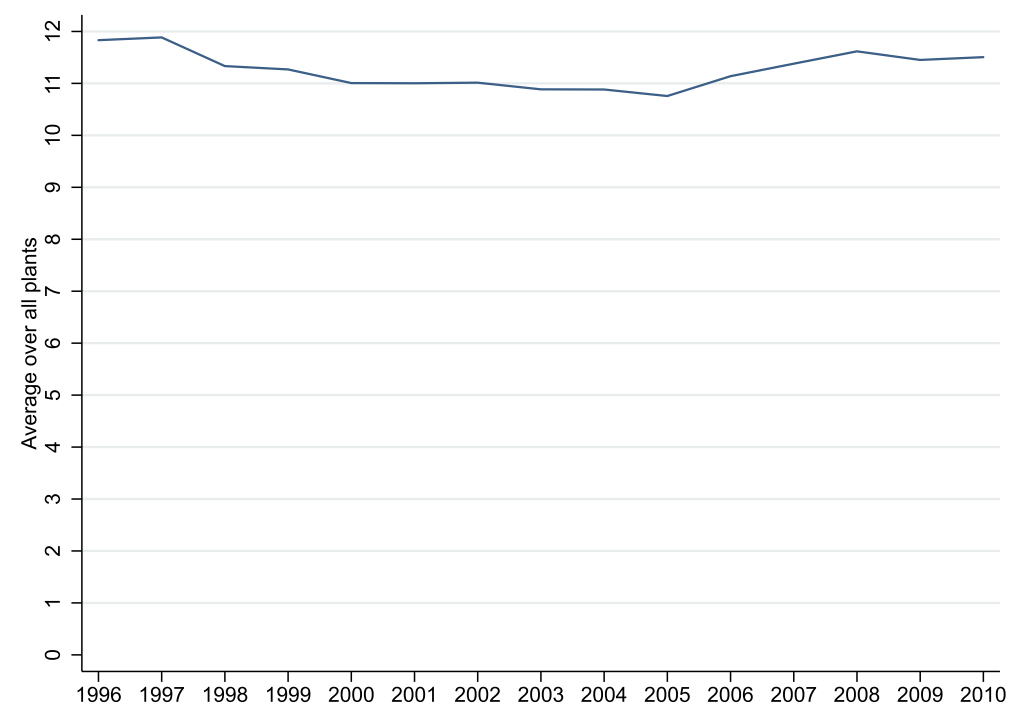

Although the IAB Establishment Panel contains information about the agreed weekly working time and overtime, this information is not available for all years. An exact calculation of working hours based on the numbers of employees in full-time and part-time jobs is also not viable. Therefore, our empirical investigation can only analyze the adjustment of the number of employees and has to neglect the working time dimension. In particular, I consider the number of employees covered by social security. ${ }^{7}$ The group of employees covered by social security is more homogenous regarding adjustment costs than the group of all employees. Therefore, the analysis of firms' adjustment behavior (e.g., adjustment speed) should be more accurate. Furthermore, I only analyze the private sector because of differences in the adjustment behavior between the public and private sector (shown descriptively by Ellguth and Kohaut 2011a). Another reason for this decision is the derivation of the empirical model, which is based on the assumption of profit maximization (see Sect. 4) that does not hold for the public sector.

Furthermore, I only consider firms' adjustment of the core workforce. In the last few years, the use of temporary agency workers has increased, especially after the reform of the Temporary Employment Agencies Act (Arbeitnehmerüberlassungsgesetz) in 2003 (see, e.g., Antoni and Jahn 2009; Spermann 2011, pp. 5-11). The temporary agency workers can serve as an alternative instrument for employment adjustment. Therefore, one could also consider them in an analysis of firms' adjustment behavior. However, I ignore temporary workers for two reasons. First, the

\footnotetext{
${ }^{7}$ Bellmann and Pahnke (2006) also use the number of employees covered by social security only. Nevertheless as a robustness check (results are available on request) I also carry out the analysis with all employees, which does not change my insights.
}

IAB Establishment Panel does not contain the number of temporary agency workers in all years of the sample. Secondly, I am interested in the adjustment of the core workforce that does not include temporary agency workers. As mentioned before, there are stricter regulations in the German labor market than in the U.S. labor market. Dismissal protection plays an important role in Germany. Analyzing the core workforce, I focus on firms' adjustment behavior with regard to employees affected by labor market regulations (e.g., dismissal protection).

Figure 1 illustrates the average number of employees covered by social security per plant from 1996 until 2010. The fluctuation over time expresses changing employment levels and thus the employment adjustment of the plants. Furthermore, it shows the phases of the business cycle (except for the first years). The average number of employees per plant is lower during the economic downturn 2002/2003 and increases again in the economic upturn after 2004. Figure 2 provides more detailed information on adjustment behavior. Every year plants increase, decrease or do not change employment, regardless of the business cycle phase. ${ }^{8}$ However, there is no clear pattern. Although a bigger share of plants reduced employment in the economic downturn 2002/2003, some plants also increased employment during that time. Another striking result is that more than 50 percent of the plants do not change their employment level over the year. This is a first evidence in favor of non-convex adjustment costs: no employment adjustment is only optimal for a plant in the presence of fixed or linear adjustment costs. ${ }^{9}$

\footnotetext{
${ }^{8}$ Increase or decrease of the employment means a change of the number of employees covered by social security from the previous to the present year.

${ }^{9}$ This evidence may be not completely convincing. One could think that no employment adjustment can also be optimal in the presence of
} 
Fig. 2 Share of the plants which decrease, do not change or increase employment (in percent)

Notes: Weighted data, private sector only

Source: IAB Establishment

Panel, waves 1996-2010, own calculations

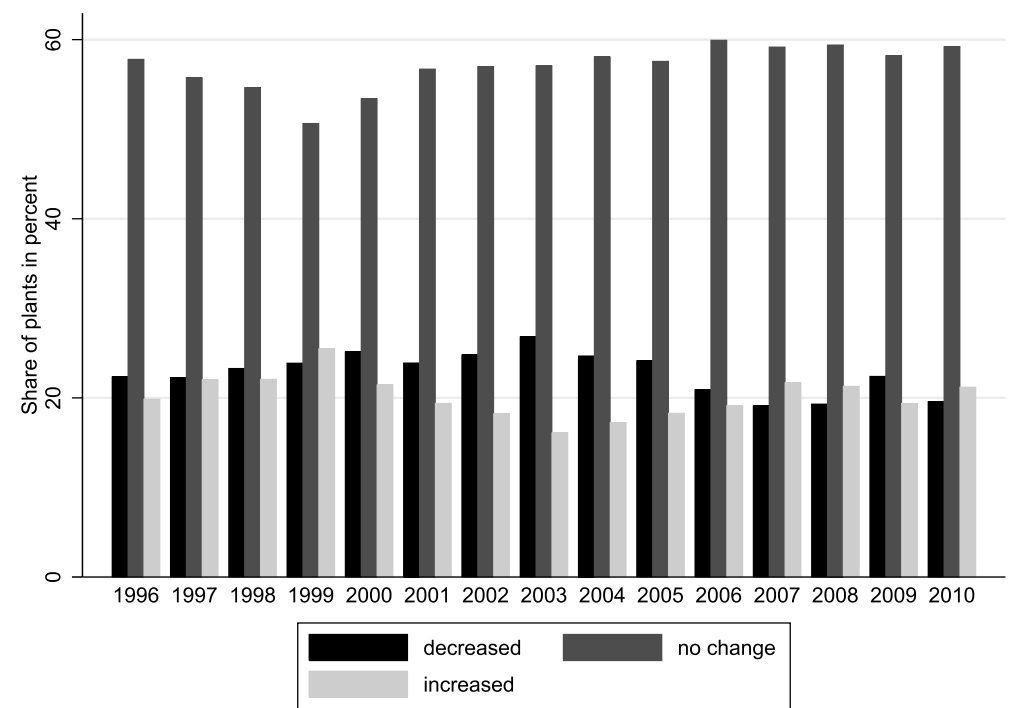

Table 1 Share of the plants which decrease, do not change or increase their employment if their employment decreased, did not change or increased in the previous year (in percent)

\begin{tabular}{|c|c|c|c|c|c|c|c|c|c|}
\hline \multirow[t]{2}{*}{ Year } & \multicolumn{3}{|c|}{$\begin{array}{l}\text { Plants whose employment decreased in } \\
\text { the previous year }\end{array}$} & \multicolumn{3}{|c|}{$\begin{array}{l}\text { Plants whose employment did not change } \\
\text { in the previous year }\end{array}$} & \multicolumn{3}{|c|}{$\begin{array}{l}\text { Plants whose employment increased in } \\
\text { the previous year }\end{array}$} \\
\hline & $\begin{array}{l}\text { thereof } \\
\text { plants, whose } \\
\text { employment } \\
\text { decreased }\end{array}$ & $\begin{array}{l}\text { thereof } \\
\text { plants, whose } \\
\text { employment } \\
\text { not chang. }\end{array}$ & $\begin{array}{l}\text { thereof } \\
\text { plants, whose } \\
\text { employment } \\
\text { increased }\end{array}$ & $\begin{array}{l}\text { thereof } \\
\text { plants, whose } \\
\text { employment } \\
\text { decreased }\end{array}$ & $\begin{array}{l}\text { thereof } \\
\text { plants, whose } \\
\text { employment } \\
\text { not chang. }\end{array}$ & $\begin{array}{l}\text { thereof } \\
\text { plants, whose } \\
\text { employment } \\
\text { increased }\end{array}$ & $\begin{array}{l}\text { thereof } \\
\text { plants, whose } \\
\text { employment } \\
\text { decreased }\end{array}$ & $\begin{array}{l}\text { thereof } \\
\text { plants, whose } \\
\text { employment } \\
\text { not chang. }\end{array}$ & $\begin{array}{l}\text { thereof } \\
\text { plants, whose } \\
\text { employment } \\
\text { increased }\end{array}$ \\
\hline 1996 & 33.37 & 47.22 & 19.41 & 18.28 & 68.40 & 13.32 & 27.07 & 48.24 & 24.69 \\
\hline 1997 & 31.26 & 40.93 & 27.81 & 17.40 & 66.67 & 15.93 & 29.70 & 41.83 & 28.47 \\
\hline 1998 & 26.78 & 44.38 & 28.84 & 19.67 & 65.26 & 15.07 & 30.71 & 37.85 & 31.44 \\
\hline 1999 & 32.27 & 39.66 & 28.07 & 20.06 & 58.27 & 21.67 & 29.80 & 39.86 & 30.33 \\
\hline 2000 & 29.98 & 44.94 & 25.08 & 19.85 & 63.13 & 17.01 & 37.03 & 38.11 & 24.86 \\
\hline 2001 & 30.93 & 45.81 & 23.26 & 20.46 & 64.55 & 14.99 & 31.16 & 43.05 & 25.80 \\
\hline 2002 & 31.88 & 44.43 & 23.69 & 21.57 & 66.10 & 12.33 & 34.14 & 41.43 & 24.42 \\
\hline 2003 & 31.08 & 46.75 & 22.17 & 21.41 & 66.48 & 12.11 & 38.52 & 40.69 & 20.79 \\
\hline 2004 & 31.14 & 47.40 & 21.46 & 19.37 & 68.60 & 12.03 & 34.16 & 41.98 & 23.86 \\
\hline 2005 & 31.64 & 43.34 & 25.03 & 19.47 & 66.64 & 13.89 & 33.99 & 42.25 & 23.77 \\
\hline 2006 & 25.24 & 48.66 & 26.10 & 17.55 & 68.05 & 14.40 & 26.32 & 49.41 & 24.28 \\
\hline 2007 & 25.30 & 46.26 & 28.44 & 15.23 & 69.26 & 15.51 & 25.58 & 42.37 & 32.05 \\
\hline 2008 & 25.55 & 48.15 & 26.30 & 15.48 & 69.28 & 15.24 & 26.27 & 39.96 & 33.77 \\
\hline 2009 & 30.11 & 41.87 & 28.02 & 17.83 & 67.70 & 14.48 & 30.60 & 44.90 & 24.50 \\
\hline 2010 & 26.95 & 41.36 & 31.68 & 15.52 & 68.77 & 15.71 & 27.91 & 44.85 & 27.25 \\
\hline
\end{tabular}

Notes: Weighted data, private sector only

Source: IAB Establishment Panel, waves 1996-2010, own calculations

convex adjustment costs if the optimum does not change. However, the optimum will not be reached in finite time. Furthermore, it is plausible that the optimal employment level changes at least within two years. Therefore, no employment adjustment two years in a row should not be observed in the presence of pure convex adjustment costs. Yet, Table 1 shows the opposite.
Table 1, which illustrates the varying adjustment decision of the plants from one year to another, further underlines the relevance of non-convexity. With convex adjustment costs plants should optimally spread employment adjustment over several time periods so that adjustment takes place in every period. But Table 1 indicates that many plants which adjust (increase or decrease) employment in one year do not further 
adjust it in the following year. ${ }^{10}$ Of course, I need econometric analysis to identify the functional form of adjustment costs more clearly.

\section{Econometric model}

As no direct data on firms' adjustment costs is available for Germany, the analysis of the firms' adjustment costs structure is based on a theoretical model of dynamic labor demand. I will compare a pure convex specification for adjustment costs with a combination of a fixed and a convex structure. ${ }^{11}$ First I derive the empirical model with convex adjustment costs which I will then compare to the empirical model with fixed and convex adjustment costs. For the model with pure convex costs, I follow the work of Kölling (1998, pp. 10-22), Nickell (1986), as well as Sargent (1978, 2010) and assume labor $L_{t}$, which is the only existing production factor, to be homogeneous.

The starting point of the model is the following profit equation: ${ }^{12}$

$$
\Pi=\sum_{t=0}^{\infty} \rho^{t}\left(a_{1} L_{t}-\frac{1}{2} a_{2} L_{t}^{2}-L_{t} w_{t}-\frac{c}{2}\left(L_{t}-L_{t-1}\right)^{2}\right) .
$$

$\Pi$ is the present value of future differences between revenues (with output following from a quadratic production function with the positive and constant parameters $a_{1}$ und $a_{2}$ and prices normalized to unity) and the sum of labor costs and convex adjustment costs (with a constant parameter $c) .{ }^{13} \rho(0<\rho<1)$ denotes the firm's discount factor.

\footnotetext{
${ }^{10}$ One could argue that results coming from annual data do not show permanent adjustment and thus cannot serve as evidence for pure convex costs because employment adjustment towards the optimum is already achieved within a year. However, the economic environment and thus the optimal employment level changes at least annually. Therefore, a plant might switch from increasing employment to decreasing, but should not stop adjustment.

${ }^{11}$ A separate analysis of a linear form is not required because its effect on adjustment behavior is nested in the fixed and convex form (see Gavosto and Sestito 1993, p. 437).

${ }^{12}$ For the profit equation some restrictive assumptions are made regarding the production function: the production function is quadratic and uses homogeneous labor as the only input factor in the short-run. While a wide range of production functions have been used in the literature, a quadratic production function was used, e.g., by Bentolila and Saint-Paul (1994), Hamermesh (1995), Kölling (1998), Sargent (1978). Note that the exact specification of the production function does not play a role for general statements about firms' adjustment behavior (see Kölling 1998, pp. 11-12). Furthermore, the fact that capital is not considered (see Hamermesh 1995, p. 624) and that labor is homogeneous (see Kölling 1998, p. 61) does not bias the results regarding firms' adjustment behavior.

${ }^{13}$ The factor $\frac{1}{2}$ in the formulas for production and adjustment costs simplifies optimization.
}

Assuming rational expectations ${ }^{14}$ profit maximization leads to the following law of motion for the firm's employment:

$L_{t}=\gamma_{1} L_{t-1}+\gamma_{2} L_{t}^{*}+v_{t}$.

According to Eq. (2) the number of employees in period $t$ is a function of the optimal employment level $L^{*}$ in period $t$ and the employment level in the previous period $L_{t-1} \cdot \gamma_{1}$ represents a measure of the adjustment speed as $\gamma_{1}$ indicates how strongly $L_{t}$ depends on $L_{t-1}$ and thus how sluggishly $L_{t}$ is adjusted towards $L_{t}^{*}$ (see Kölling 1998, p. 21). Low adjustment costs cause a high adjustment speed and result in a low value for $\gamma_{1}$. Finally, $v_{t}$ is the residual term when estimating Eq. (2).

Following the traditional approach in the literature, Eq. (2) will be expressed with employment levels in logarithmic form. ${ }^{15}$

$l_{t}=\lambda_{1} l_{t-1}+\lambda_{2} l_{t}^{*}+v_{t}$,

where lower-case letters represents logarithms. Yet, I still cannot estimate Eq. (3) in its current form since the data does not contain information about the optimal employment level. To solve this problem, I follow Kölling (1998, p. 132). Assuming a Cobb-Douglas production function and using the implication that in the long-run optimum the real wage equals the marginal product of labor (see Breitung 1992, p. 144) one can show that the logarithm of the optimal employment level depends on the logarithm of the output and the logarithm of the real wage rate. After another transformation, which is obligatory because the IAB Establishment Panel does not contain information about output and real wage rate, $l_{t}^{*}$ can be expressed as a linear function of the logarithm of the turnover and the logarithm of the nominal wage bill per employee (see Breitung 1992, p. 170). ${ }^{16}$ In addition, further controls are included in the empirical model which is given by:

$l_{t}=\alpha_{1} l_{t-1}+\beta_{1} \log$. turnover $+\beta_{2} \log$. wage $+\boldsymbol{\beta} \boldsymbol{x}_{t}+v_{t}$.

The vector of controls $\boldsymbol{x}_{t}$, which are assumed to be strictly exogenous, includes several variables for employment structure like: the share of female employees in the

\footnotetext{
${ }^{14}$ Equation (1) is maximized for the derivation of Eq. (2). The result of this profit maximization is an Euler equation, which contains expectations about future labor demand (not shown in this paper). In this context rational expectations are assumed, which is a suitable and often used assumption (see Kölling 1998, p. 148; Bresson et al. 1992, p. 361).

${ }^{15}$ Clearly, Eq. (3) does not follow directly from Eq. (2). I use the logarithmic expression in the tradition of the previous studies, e.g., Arellano and Bond (1991), Bellmann and Pahnke (2006), Bohachova et al. (2011), Breitung (1992, 1994), Buch and Lipponer (2010), Cooper and Willis (2009), FitzRoy and Funke (1998), Funke et al. (1998), Kölling (1998), Lapatinas (2009) and Rottmann and Ruschinski (1998).

${ }^{16}$ For details about the algebraic transformation I refer to Kölling (1998, pp. 132-134).
} 
workforce, the share of qualified employees, the share of part-time employees, the share of fixed-term employees and the share of employees covered by social security in the regression (see Bellmann and Pahnke 2006, p. 207; Kölling 1998 , p. 134). Additionally, I consider a dummy variable whether the managers regarded the profit situation in the previous year as very good or good, a dummy reflecting modern production technology, a dummy reflecting the existence of a works council (lagged by one year to avoid endogeneity problems), a dummy reflecting the existence of a collective agreement (lagged by one year to avoid endogeneity problems), two dummies indicating whether the managers expect an increasing or decreasing turnover and a set of dummy variables for the industry and the year.

Regarding the share of female employees, two effects in the labor demand equation are possible. On the one hand, women in stereotyped occupations (e.g., secretary) are overrepresented in small plants, which would lead to a negative coefficient. On the other hand, women are rather concentrated in the production of bulk commodities or in simple services which are carried out in bigger plants. This in turn implies a positive coefficient. There are also ambiguous expectations regarding the sign of the share of qualified employees. As they are more productive than other employees, the plant is able to produce the same output with less workers (negative coefficient). However, the higher productivity can result in higher economic success and so in more labor demand (positive coefficient). The sign of the share of parttime employees is expected to be positive, as a plant needs more employees to produce same output. The share of fixedterm employees should also has a positive effect because for fixed-term employees adjustment costs are lower, especially dismissal costs (see Goux et al. 2001, p. 548; Varejão and Portugal 2007a, p. 159). Thus, labor demand can be higher without adjustment costs increasing too much. Both signs are possible for the share of employees covered by social security. On the one hand, these employees show higher adjustment costs compared to marginal employees. If adjustment is mainly achieved by changing the number of employees covered by social security, a higher labor demand increases costs in case of adjustment (negative coefficient). On the other hand, the employees covered by social security could have higher productivity compared to other employees and so the same effects occur as with qualified employees (positive/negative coefficient).

The dummy variable whether the managers regarded the profit situation in the previous year as very good or good is expected to have a positive sign, as plants in a good economic situation are likely to show a higher labor demand (see Bellmann and Kölling 1997, p. 98). The same should hold for the dummy variable reflecting modern production technology, as it leads to higher productivity and thus to more labor demand. No clear effect can also be predicted for the dummy variable reflecting the existence of a works council. Following the exit-voice-approach, a works council results in a better economic situation for the plant with less fluctuation and, hence, less adjustment (see, e.g., Freeman and Medoff 1984; Hirsch et al. 2010; Jirjahn 2010). Thus, more labor demand and a positive coefficient can be expected. However, the works council with its codetermination rights (e.g., in case of dismissal or social plans) and rentseeking activities may increases labor costs, especially adjustment costs (see, e.g., Addison and Teixeira 2006; Hirsch et al. 2010; Jirjahn 2010; Müller-Jentsch 1997, pp. 265272). The result would be a lower labor demand and a negative coefficient. The dummy variable reflecting the existence of a collective agreement should have similar negative effects. Further, as a collective agreement indicates higher union power, it may also lead to higher adjustment costs (see Jaramillo et al. 1993).

If the plant expects a higher turnover in the future connected with a higher labor demand, it will start the upward employment adjustment in the present period because of the convex cost structure (see Bellmann and Pahnke 2006, p. 207). The result is a positive coefficient for the dummy variable indicating whether the managers expect increasing turnover and a negative coefficient in the decreasing case.

For the analysis of the asymmetry I estimate the following model including interaction terms ${ }^{17}$ based on Jaramillo et al. (1993) as well as Schiantarelli and Sembenelli (1993):

$$
\begin{aligned}
l_{t}= & \alpha_{1} l_{t-1}+\Delta \alpha_{1} \delta l_{t-1}+\beta_{1} \log . \text { turnover } \\
& +\Delta \beta_{1} \delta \text { log.turnover }+\beta_{2} \log \text {.wage } \\
& +\Delta \beta_{2} \delta \text { log.wage }+\boldsymbol{\beta} \boldsymbol{x}_{t}+\Delta \boldsymbol{\beta} \delta \boldsymbol{x}_{t}+v_{t}
\end{aligned}
$$

with

$\delta= \begin{cases}1, & \text { if } L_{t}>L_{t-1} \\ 0, & \text { else. }\end{cases}$

Different costs for upward and downward adjustment and thus different adjustment speeds are reflected in different values for $\alpha_{1}$. A negative $\Delta \alpha_{1}$ indicates a faster adjustment in the case of upward adjustment and so higher dismissal costs compared to the costs of hiring.

As Eq. (4) is a dynamic panel model, I use an system GMM estimator (GMM-SYS/Arellano-Bover estima-

\footnotetext{
${ }^{17}$ In the empirical analysis and interpretation of the results it is important to note that the interaction terms might be affected by endogeneity since the dummy variable depends on firms' employment adjustment, which determines also $l_{t}$. Therefore, a new employment level $l_{t}$ after adjustment might also affects the dummy variable. But Jaramillo et al. (1993, p. 642) consider this with reference to Heckman (1978) not as a problem due to the use of a dynamic panel estimation according to Arellano and Bond (1991). I use a dynamic panel as well with a similar approach.
} 
tor) (see Arellano and Bover 1995). ${ }^{18}$ This estimator is an extension of the difference GMM estimator (GMMDIFF/Arellano-Bond estimator) (see Arellano and Bond 1991). The GMM-SYS estimator uses previous levels $l_{t-2}$, $\ldots, l_{1}$ as instruments for the first differences $\Delta l_{t-1}$ like the GMM-DIFF estimator and additionally lagged first differences $\Delta l_{t-1}, \ldots, \Delta l_{2}$ as instruments for the levels. Comparing the two estimators, the GMM-SYS estimator is more efficient and yields better results (see, e.g., Bond and van Reenen 2007, p. 4452; Blundell and Bond 1998, p. 116; Blundell and Bond 2000, p. 339; Blundell et al. 2000). Additionally, I use the more robust two-step version of the estimator, which leads to an additional efficiency increase if the standard errors are Windmeijer-corrected (see, e.g., Bond 2002, p. 147; Roodman 2009, p. 97; Windmeijer 2005, pp. 44-46).

Every plant adjusts employment according to Eq. (4) or (5) if pure convex adjustment costs are assumed. But if a fixed and convex structure is assumed, these equations are just relevant for those plants which actually decide to adjust. And not every plant selects itself in the state of employment adjustment so that Eq. (4) or (5) is not relevant for every plant. The selection process, which leads to the sample of adjusting plants, is based on the fixed cost component. Depending on fixed adjustment costs, the plant will only adjust employment if the profit gained from adjustment exceeds costs or, put differently, if the difference to the optimal level $L^{*}$ is big enough. Hence, adjustment only occurs and plants select themselves in the state of employment adjustment if

$k<\left|L_{t-1}-L_{t}^{*}\right|$

with a threshold value $k$. Otherwise the plant will keep the employment level of the previous period $\left(L_{t}=L_{t-1}+v_{t}\right)$. For fixed and convex adjustment costs, I thus arrive at a switching-regression where the inequality (6) determines whether the employment level $L_{t}$ is changed according to Eqs. (4) or (5), respectively, or whether the employment level $L_{t}$ stays constant $\left(L_{t}=L_{t-1}+v_{t}\right){ }^{19}$ There are different approaches estimating a switching-regression (e.g., D-method). In my analysis I use a two-step procedure according to Maddala (1994, pp. 223-228). In a first step a probit model is estimated for the selection or switching. Afterwards, in a second step the current equation-in my case Eq. (4) or (5)—is estimated with a selection term à la Heck-

\footnotetext{
${ }^{18}$ For details about the analysis of dynamic panel models I refer to (Baltagi 2008, Chap. 8).

${ }^{19}$ For details on switching-regressions see, e.g., Cameron and Trivedi (2005, pp. 555-557), Goldfeld and Quandt (1976) as well as Maddala (1986).
}

man estimated from the probit model. ${ }^{20,21}$ To obtain correct standard errors, the bootstrap is used. Note that the results of this second step can be interpret in the same way as in the dynamic panel without the selection term.

The basis for the probit model is inequality (6), which determines the latent variable. The firm's decision about employment adjustment depends on the following inequality and thus $L_{t} \neq L_{t-1}$ if:

$$
\begin{aligned}
& \left|L_{t-1}-L_{t}^{*}\right|-k>0 \\
& \quad \Leftrightarrow\left|L_{t-1}-\sum_{i} X_{i}\right|-k>0
\end{aligned}
$$

in which $\sum_{i} X_{i}$ are the determinants of $L_{t}^{*}$. The relation described by Eq. (2) is also given for $L_{t-1}$ and so labor demand in $t-1$ depends on $L_{t-2}$ as well as $L_{t-1}^{*} \cdot{ }^{22}$ This leads to the following condition for $L_{t} \neq L_{t-1}$ :

$$
\begin{aligned}
& \Leftrightarrow\left|\gamma_{1} L_{t-2}+\gamma_{2} L_{t-1}^{*}-L_{t}^{*}\right|-k>0 \\
& \Leftrightarrow\left|\gamma_{1} L_{t-2}+\gamma_{2} \sum_{i} \Delta X_{i t-1}-\sum_{i} \Delta X_{i t}\right|-k>0 .
\end{aligned}
$$

Besides $L_{t-2}$, the decision for adjustment depends on the change of $L^{*}$ or its determinants from the previous to the current period. In the analysis the model for the latent variable in the probit model is given by:

$y_{t}^{*}=\rho l_{t-2}+\boldsymbol{\sigma}\left|\triangle \boldsymbol{x}_{t}\right|+\boldsymbol{\theta} z_{t}+u_{t}$.

In addition to $l_{t-2}$, the vector $\left|\Delta \boldsymbol{x}_{t}\right|$ in Eq. (7) contains the absolute value of the percentage change of turnover and wage bill per employee as well as the absolute values of changes in percentage points of the various employment shares. Furthermore, $\left|\Delta \boldsymbol{x}_{t}\right|$ contains two dummy variables indicating whether managers' valuation of the profit situation has increased or decreased and two dummy variables indicating whether the production technology has been upgraded or downgraded. I also include two dummy variables indicating whether managers are expecting a change of turnover in the current period after expecting no change

\footnotetext{
${ }^{20}$ There are other studies which analyze fixed adjustment costs by using a Heckman approach (see, e.g., Nilsen et al. 2007). But Nilsen et al. (2007), for instance, do not use a dynamic panel model as the second step.

${ }^{21}$ For details on sample selection and dynamic panel data models and applications see, e.g., Garcia et al. (2007), Jiménez-Martín (2006), Jiménez-Martín and Garcia (2010) as well as Lodigiani and Salomone (2012).

${ }^{22}$ The reason for the use of Eq. (2) although $L_{t-1}$ and $X_{i}$ are both observed separately is technical simplification. Note that the selection depends not on $L_{t-1}$ and $X_{i}$ as single variables but on the difference of these two, which is not directly given in the data and not easy to generate.
} 
in the previous period and whether managers are expecting no change of turnover in the current period after expecting a change in the previous period. These variables represent also the exclusion restrictions. Labor demand depends on the level-variables and is not determined by the changes. Finally, the vector $z_{t}$ includes some of the variables from Eq. (4), which I expect to show an impact on fixed adjustment costs, too. These variables affect the threshold value $k$ in Eq. (6). The existence of a works council or a collective agreement, which leads to higher adjustment costs, results in a higher $k$. Therefore, the profit gained from adjustment and so the difference $\left|L_{t-1}-L_{t}^{*}\right|$ has to be bigger. I also include dummy variables indicating whether the managers regarded the profit situation in the previous year as very good or good, reflecting a modern production technology, indicating whether managers expect an increasing or decreasing turnover and sets of industry and year dummies. ${ }^{23}$

\section{Empirical results}

First, I estimate the model with pure convex adjustment costs. In doing so, I also investigate a potential asymmetry in adjustment costs. Second, I estimate the model with fixed and convex costs in a switching-regression approach. This estimation is only done for plants which actually adjust employment. Afterwards, I compare the results of both models and decide which better suits the data. ${ }^{24}$

Table 2 reports the estimation results of the model with convex, symmetric adjustment costs (specification (4)). ${ }^{25}$ The coefficient $\alpha_{1}$ for the lagged logarithmic number of employees covered by social security has the value 0.6746 in Western Germany. It represents a median adjustment of approximately 1.8 years, implying a lower adjustment speed compared to the result of Kölling (1998, p. 143), who, analyzing West German plants during 1993-1996, finds a median adjustment of around 0.7 years. ${ }^{26}$ However, our result is in line with results from other studies for Germany. The bulk of these studies show a median adjustment between 0.7 and

\footnotetext{
${ }^{23}$ The panel nature of the data is considered by using year dummies and clustering standard errors at establishment level.

${ }^{24}$ Because of the existing general differences between the labor markets in Western and Eastern Germany I will conduct the econometric analysis separately for the two German regions.

${ }^{25}$ Summary statistics are reported in Table 7 in the Appendix.

${ }^{26}$ The median adjustment is the time span the plant needs to do half of the adjustment towards the optimum. It is based on the equation $\alpha_{1}^{t}=0.5$, which is solved for $t$ (see Hamermesh 1993a, p. 248) and which has the dimension 'years'. For an alternative interpretation of $\alpha_{1}$ see Funke et al. $(1998$, p. 231$)$. $\left(1-\alpha_{1}\right)$ is the share of the adjustment towards the optimum, occurring between the previous and the current period.
}

7.7 years. ${ }^{27}$ Furthermore, Table 5 contains the elasticities of labor demand regarding nominal wage rate and turnover, respectively: The long-run value for the wage rate is -0.27 and for turnover 0.10 . These results are also in line with other studies for Germany, which not all use dynamic labor demand models for the analysis. The share of qualified employees has a negative sign and so their higher productivity enables the plant to produce the same output with fewer people. As expected, the coefficient of the share of part-time employees is greater than zero. The plant needs more employees for the same output. Furthermore, I find a positive effect for the share of fixed-term employees as well as for the share of employees covered by social security. Moreover, a good profit situation leads to higher labor demand which is also reflected by the signs of the dummy variables for the expected turnover. In contrast, the existence of a works council reduces labor demand.

Table 2 also contains various summary statistics to assess the quality of the models estimated. The value of the Hansen test indicates a misspecification. ${ }^{28}$ However, one has to consider that the Hansen test provides no unambiguous and strong statements (see Roodman 2009, p. 98) and that even with a positive result it is possible that the model is biased (see Wooldridge 2010, p. 135). I continue to rely on my model because an Arellano-Bond-Test does not indicate a second-order serial correlation in the first-differenced residuals. ${ }^{29}$ The table also shows the value of the Theil $\mathrm{U}$ statistic as a measure for the predictive power (see Greene 2012 , p. 128). The basis for the calculation is an estimation for the period 1996-2007 which is then used to predict the years 2008-2010. A higher value indicates a lower predictive power, but a single value is not meaningful. I use the Theil U statistic to compare the predictive power of different models.

For Eastern German plants the coefficient $\alpha_{1}$ has the value 0.6600 which implies a median adjustment after approx. 1.7 years. Apparently, the adjustment process is faster and so adjustment costs are lower in Eastern Germany compared to Western Germany, which has also been found by Bellmann and Pahnke (2006, pp. 212-213) as well as Fuchs

\footnotetext{
${ }^{27}$ The reasons for the wide range of results might be, among other things, a different observation period or a different estimation method. ${ }^{28}$ In order to improve the Hansen test, I ran several alternative models. An estimation of the models with two lags still leads to a Hansen test which indicates a misspecification. Another reason for the indication of misspecification might be the assumption of strict exogeneity for all regressor variables, especially turnover, wage and the variables for the employment structure. But assuming endogeneity for turnover, wage and the variables for the employment structure still results in a Hansen test that indicates a misspecification.

${ }^{29}$ Fuchs (2010, p. 123) uses the same argument for a further analysis of her (seemingly misspecified) model. All Arellano-Bond-Tests in my study indicate no second-order serial correlation in the first-differenced residuals unless otherwise mentioned.
} 
Table 2 Estimation of the basic model of dynamic labor demand with convex adjustment costs ${ }^{\mathrm{a}}$ (only private sector; 1996-2010; two-step GMM-SYS estimator; dependent variable is log number of employees covered by social security)

\begin{tabular}{|c|c|c|c|c|}
\hline \multirow[t]{2}{*}{ Explanatory variables } & \multicolumn{2}{|c|}{ Western Germany } & \multicolumn{2}{|l|}{ Eastern Germany } \\
\hline & coeff. & std.error & coeff. & std.error \\
\hline Lagged employment $l_{t-1}$ & $0.6746^{* * *}$ & 0.0252 & $0.6600^{* * *}$ & 0.0232 \\
\hline Turnover $(\log )$ & $0.0310^{* * *}$ & 0.0099 & $0.0238^{* *}$ & 0.0110 \\
\hline Nom. wage bill per employee (log) & $-0.0867^{* * *}$ & 0.0082 & $-0.0783^{* * *}$ & 0.0101 \\
\hline Share of female employees (in percent) & 0.0002 & 0.0003 & -0.0003 & 0.0003 \\
\hline Share of qualified employees (in percent) & $-0.0013^{* * *}$ & 0.0001 & $-0.0014^{* * *}$ & 0.0002 \\
\hline Share of part-time employees (in percent) & $0.0006^{* * *}$ & 0.0002 & $0.0011^{* * *}$ & 0.0002 \\
\hline Share of fixed-term employees (in percent) & $0.0020^{* * *}$ & 0.0004 & $0.0024^{* * *}$ & 0.0004 \\
\hline Share of employees covered by social security (in percent) & $0.0164^{* * *}$ & 0.0005 & $0.0202^{* * *}$ & 0.0006 \\
\hline Profit situation $\ddagger($ dummy: very good/good $=1)$ & $0.0258^{* * *}$ & 0.0031 & $0.0259^{* * *}$ & 0.0038 \\
\hline Modern production technology (dummy: 1 or 2 on 5-point scale $=1$ ) & 0.0055 & 0.0038 & $0.0122^{* *}$ & 0.0048 \\
\hline Works council $\ddagger($ dummy: yes $=1)$ & $-0.0299^{* * *}$ & 0.0100 & -0.0105 & 0.0124 \\
\hline Covered by collective agreement $\ddagger($ dummy: yes $=1)$ & 0.0035 & 0.0054 & 0.0021 & 0.0053 \\
\hline Firm expects turnover increase (dummy: yes $=1$ ) & $0.0233^{* * *}$ & 0.0029 & $0.0399^{* * *}$ & 0.0041 \\
\hline Firm expects turnover reduction (dummy: yes $=1$ ) & $-0.0366^{* * *}$ & 0.0033 & $-0.0586^{* * *}$ & 0.0040 \\
\hline Constant & -0.0838 & 0.1505 & $-0.5030^{* * *}$ & 0.1590 \\
\hline Industry dummies & yes & & yes & \\
\hline Year dummies & $\operatorname{yes}^{* * *}$ & & $\operatorname{yes}^{* * *}$ & \\
\hline Number of observations (plant-years) & 49577 & & 38141 & \\
\hline Wald (37) & $4248.20^{* * *}$ & & $5602.03^{* * *}$ & \\
\hline Hansen (103) & $122.5397^{*}$ & & $184.8406^{* * *}$ & \\
\hline Arellano-Bond (m1 | m2) & $-12.52^{* * *}$ & -1.47 & $-14,66^{* * *}$ & 1.57 \\
\hline Theil U & 0.1180 & & 0.1367 & \\
\hline
\end{tabular}

${ }^{a}$ The table presents coefficients and Windmeijer-corrected standard errors. Reference categories of the dummy variable groups: no turnover change expected, agriculture and forestry, 1996 and 1997. Significance levels: ${ }^{*} p<0.1 ;{ }^{* *} p<0.05 ;{ }^{* * *} p<0.01$. Arellano-Bond (m1 I m2) are tests for first- and second-order serial correlation in the first differenced residuals. For the Theil U statistics the years 2008 to 2010 are predicted based on an estimation of the years 1996 to 2007. $\neq$ Indicates that the information refers to the previous year

Source: IAB Establishment Panel, waves 1996-2010

(2010, pp. 168-169). However, the difference to Western Germany is not statistically significant as the confidence intervals overlap. The long-run elasticities in Eastern Germany are 0.07 for turnover and -0.23 for wage rate. The other coefficients are not qualitatively different to Western Germany. Only the effect for the existence of a works council is statistically insignificant for Eastern German plants, and modern production technology has a statistically significant positive sign. Apparently, plants with modern technology have higher productivity and demand more employees. Since an Arellano-Bond-Test indicates no second-order serial correlation in the first-differenced residuals, I use the model although the Hansen test indicates a misspecification.

Next, I analyze a potential asymmetry of the adjustment costs by estimating model (5) including the interaction terms for the direction of adjustment (see Table 3) ${ }^{30}$ For Western and Eastern Germany the coefficient $\Delta \alpha_{1}$ is less than zero, suggesting that employment adjustment proceeds faster in case of an employment increase. Besides, all the interaction terms together are statistically significant, indicating asymmetric adjustment costs with dismissal costs exceeding hiring costs. ${ }^{31}$ Furthermore, the Theil U statistics indicate that

\footnotetext{
${ }^{30}$ The model for Eastern Germany is estimated with $l_{t-1}$ and additional $l_{t-2}$ such that the Arellano-Bond-Test does not indicate a second-order serial correlation in the first-differenced residuals.

${ }^{31}$ Note that the analysis is not a clear comparison of plants increasing employment with plants decreasing employment because the reference category for the dummy variable are plants that decrease or do not change employment. Therefore as a robustness check, I also estimate the model with a dummy variable indicating whether the plant decreases employment (results are available on request). This also results in estimates indicating that dismissal costs exceeds hiring costs.
} 
Table 3 Estimation of the basic model of dynamic labor demand with convex adjustment costs and an asymmetric cost structure ${ }^{\text {a }}$ (only private sector; 1996-2010; two-step GMM-SYS estimator; dependent variable is log number of employees covered by social security)

\begin{tabular}{|c|c|c|c|c|}
\hline \multirow[t]{2}{*}{ Explanatory variables } & \multicolumn{2}{|c|}{ Western Germany } & \multicolumn{2}{|l|}{ Eastern Germany } \\
\hline & coeff. & std.error & coeff. & std.errol \\
\hline Lagged employment $l_{t-1}$ & $0.7280^{* * *}$ & 0.0225 & $0.7535^{* * *}$ & 0.0197 \\
\hline$l_{t-1} \times \operatorname{dummy}(1=L$ increased between $t-1$ and $t)$ & $-0.0747^{* * *}$ & 0.0054 & $-0.0793^{* * *}$ & 0.0075 \\
\hline Turnover $(\log )$ & 0.0108 & 0.0090 & 0.0059 & 0.0116 \\
\hline Nom. wage bill per employee (log) & $-0.0535^{* * *}$ & 0.0071 & $-0.0606^{* * *}$ & 0.0098 \\
\hline Share of female employees (in percent) & 0.0001 & 0.0002 & -0.0001 & 0.0003 \\
\hline Share of qualified employees (in percent) & $-0.0009^{* * *}$ & 0.0001 & $-0.0010^{* * *}$ & 0.0002 \\
\hline Share of part-time employees (in percent) & $0.0005^{* * *}$ & 0.0001 & $0.0008^{* * *}$ & 0.0002 \\
\hline Share of fixed-term employees (in percent) & 0.0001 & 0.0004 & 0.0001 & 0.0004 \\
\hline Share of employees covered by social security (in percent) & $0.0125^{* * *}$ & 0.0004 & $0.0155^{* * *}$ & 0.0006 \\
\hline Profit situation $\$$ (dummy: very good/good $=1$ ) & $0.0200^{* * *}$ & 0.0030 & $0.0252^{* * *}$ & 0.0042 \\
\hline Modern production technology (dummy: 1 or 2 on 5 -point scale $=1$ ) & $0.0069^{*}$ & 0.0036 & $0.0147^{* * *}$ & 0.0053 \\
\hline Works council $\ddagger($ dummy: yes $=1)$ & -0.0131 & 0.0102 & -0.0145 & 0.0131 \\
\hline Covered by collective agreement $\ddagger($ dummy: yes $=1)$ & -0.0011 & 0.0050 & -0.0003 & 0.0058 \\
\hline Firm expects turnover increase (dummy: yes $=1$ ) & -0.0006 & 0.0030 & 0.0020 & 0.0047 \\
\hline Firm expects turnover reduction (dummy: yes $=1$ ) & $-0.0377^{* * *}$ & 0.0032 & $-0.0539^{* * *}$ & 0.0043 \\
\hline Constant & 0.0850 & 0.1337 & $-0.4445^{* * *}$ & 0.1592 \\
\hline Industry dummies & yes & & yes & \\
\hline Year dummies & yes $^{* * *}$ & & $\operatorname{yes}^{* * *}$ & \\
\hline Other interactions with dummy $(1=L$ increased between $t-1$ and $t)$ & yes $^{* * *}$ & & yes $^{* * *}$ & \\
\hline Number of observations (plant-years) & 49423 & & 30317 & \\
\hline Wald (74/73) & $8571.57^{* * *}$ & & $10220.42^{* * *}$ & \\
\hline Hansen $(103 / 101)$ & 109.3018 & & $162.172^{* * *}$ & \\
\hline Arellano-Bond (m1 | m2) & $-10.94^{* * *}$ & -0.03 & $-10.35^{* * *}$ & 0.76 \\
\hline Theil U & 0.1080 & & 0.0873 & \\
\hline
\end{tabular}

${ }^{a}$ The table presents coefficients and Windmeijer-corrected standard errors. Reference categories of the dummy variable groups: no turnover change expected, agriculture and forestry, 1996 and 1997 (Eastern Germany: additional 1998). Significance levels: ${ }^{*} p<0.1{ }^{* *} p<0.05$; ${ }^{* * *} p<0.01$. In order to avoid a correlation with the error term, I use $l_{t-2}$ instead of $l_{t-1}$ for the interaction. The model for Eastern Germany is estimated with two lags to get an Arellano-Bond-Test which does not indicate second-order serial correlation in the first-differenced residuals. Arellano-Bond (m1 I $\mathrm{m} 2$ ) are tests for first- and second-order serial correlation in the first differenced residuals. For the Theil U statistics the years 2008 to 2010 are predicted based on an estimation of the years 1996 to 2007. $\$$ Indicates that the information refers to the previous year

Source: IAB Establishment Panel, waves 1996-2010

the model with asymmetric adjustment costs has a higher predictive power.

So far, the results indicate that adjustment costs are asymmetric with dismissal costs exceeding hiring costs. ${ }^{32}$ In a next step, Table 4 presents the results for the model with fixed and convex as well as asymmetric adjustment costs. ${ }^{33}$ The results of the probit model which is estimated in the

\footnotetext{
${ }^{32}$ More precisely, as the analysis is based on all separations, it is not only dismissal costs but separation costs in total which exceed hiring costs.

${ }^{33}$ Only plants which adjust their employment (change their number of employees covered by social security from the previous to the present year) are considered in this analysis. This sample selection is corrected by including a selection term in the model (see section 4 ).
}

first step to calculate the selection terms are given in Table 8 in the Appendix. ${ }^{34}$ In Western Germany the coefficient $\alpha_{1}$ has the value 0.7877 , which results in a median adjustment of approximately 2.9 years. As in the pure convex case, I

\footnotetext{
${ }^{34}$ As a robustness check, I estimated the probit model also with $l_{t-1}$ instead of $l_{t-2}$ as well as with the change of the employment shares from the pre-previous to the previous period instead of the change from the previous to the current one. But these variations lead to a lower predictive power in the probit model, do not really result in a different outcome for the second step and the Hansen test still indicates a misspecification. Using neither $l_{t-1}$ nor $l_{t-2}$ the Hansen test is getting even worse. I also estimated the probit model without the level-variables, although some of these are statistically significant (see Table 8 in the Appendix). Again, this does neither improve the Hansen test nor the predictive power of the probit model.
} 
Table 4 Estimation of the basic model of dynamic labor demand with fix and convex adjustment costs and an asymmetric cost structure ${ }^{\mathrm{a}}$ (only private plants which adjust their level of employment; 1996-
2010; two-step GMM-SYS estimator; dependent variable is log number of employees covered by social security)

\begin{tabular}{|c|c|c|c|c|}
\hline \multirow[t]{2}{*}{ Explanatory variables } & \multicolumn{2}{|c|}{ Western Germany } & \multicolumn{2}{|c|}{ Eastern Germany } \\
\hline & coeff. & std.error & coeff. & std.error \\
\hline Lagged employment $l_{t-1}$ & $0.7877^{* * *}$ & 0.0457 & $0.7493^{* * *}$ & 0.0582 \\
\hline$l_{t-1} \times \operatorname{dummy}(1=L$ increased between $t-1$ and $t)$ & $0.0629^{* * *}$ & 0.0090 & $-0.0744^{* * *}$ & 0.0158 \\
\hline Turnover $(\log )$ & -0.0052 & 0.0190 & 0.0186 & 0.0393 \\
\hline Nom. wage bill per employee $(\log )$ & $-0.0912^{* * *}$ & 0.0172 & $-0.1032^{* * *}$ & 0.0250 \\
\hline Share of female employees (in percent) & 0.0002 & 0.0006 & -0.0003 & 0.0010 \\
\hline Share of qualified employees (in percent) & $-0.0016^{* * *}$ & 0.0003 & $-0.0015^{* * *}$ & 0.0005 \\
\hline Share of part-time employees (in percent) & $0.0008^{*}$ & 0.0004 & $0.0013^{* *}$ & 0.0006 \\
\hline Share of fixed-term employees (in percent) & 0.0001 & 0.0008 & 0.0007 & 0.0008 \\
\hline Share of employees covered by social security (in percent) & $0.0162^{* * *}$ & 0.0010 & $0.0194^{* * *}$ & 0.0021 \\
\hline Profit situation $\ddagger$ (dummy: very good $/$ good $=1)$ & $0.0195^{* * *}$ & 0.0053 & $0.0411^{* * *}$ & 0.0098 \\
\hline Modern production technology (dummy: 1 or 2 on 5-point scale $=1$ ) & $0.0116^{* *}$ & 0.0057 & $0.0276^{* *}$ & 0.0140 \\
\hline Works council $\ddagger($ dummy: yes $=1)$ & -0.0155 & 0.0174 & -0.0153 & 0.0280 \\
\hline Covered by collective agreement $\ddagger$ (dummy: yes $=1)$ & -0.0053 & 0.0110 & -0.0070 & 0.0129 \\
\hline Firm expects turnover increase (dummy: yes $=1$ ) & 0.0042 & 0.0051 & $0.0195^{*}$ & 0.0107 \\
\hline Firm expects turnover reduction (dummy: yes $=1$ ) & $-0.0341^{* * * *}$ & 0.0049 & $-0.0494^{* * *}$ & 0.0098 \\
\hline Constant & 0.2033 & 0.4267 & $-0.9315^{*}$ & 0.4873 \\
\hline Industry dummies & yes & & yes & \\
\hline Year dummies & yes $^{* * *}$ & & yes & \\
\hline Selection term & yes $^{* * *}$ & & yes $^{* *}$ & \\
\hline Other interactions with dummy $(1=L$ increased between $t-1$ and $t)$ & yes $^{* * *}$ & & yes $^{* * *}$ & \\
\hline Number of observations (plant-years) & 28824 & & 17577 & \\
\hline Wald $(73 / 70)$ & $4280.76^{* * *}$ & & $9928.60^{* * *}$ & \\
\hline Hansen $(103 / 100)$ & $380.1639^{* * *}$ & & $422.321^{* * *}$ & \\
\hline Arellano-Bond (m1 I m2) & $-5.91^{* * *}$ & 0.45 & $-6.80^{* * *}$ & 1.13 \\
\hline Theil U & 0.0794 & & 0.0841 & \\
\hline
\end{tabular}

${ }^{\mathrm{a}}$ The table presents coefficients and standard errors that are calculated from a bootstrapping with 150 replications. Reference categories of the dummy variable groups: no turnover change expected, agriculture and forestry, 1996 and 1997 (Eastern Germany: additional 1998 and 1999 ). Significance levels: ${ }^{*} p<0.1 ;{ }^{* *} p<0.05 ;{ }^{* * *} p<0.01$. In order to avoid a correlation with the error term, I use $l_{t-2}$ instead of $l_{t-1}$ for the interaction. The model for Eastern Germany is estimated with two lags to get an Arellano-Bond-Test which does not indicate second-order serial correlation in the first-differenced residuals. Arellano-Bond $(\mathrm{m} 1 \mathrm{I} \mathrm{m} 2)$ are tests for first- and second-order serial correlation in the first differenced residuals. For the Theil U statistics the years 2008 to 2010 are predicted based on an estimation of the years 1996 to 2007 . $¥$ Indicates that the information refers to the previous year

Source: IAB Establishment Panel, waves 1996-2010

have evidence for asymmetric adjustment costs in Western and Eastern Germany. Thus, the 2.9 years are the median adjustment for employment decrease in Western Germany. If employment increases, the plant adjusts approximately 0.7 years faster. The corresponding values are 2.4 years (employment decrease) and 1.8 years (employment increase) for Eastern German plants and hence the difference is 0.6 years. The long-run elasticity for the wage rate is $-0.19 /-0.43$ (employment increase/decrease) in Western Germany and $-0.12 /-0.76$ in Eastern Germany. As the effect of turnover is statistically insignificant, I report no long-run elasticities for turnover. ${ }^{35}$ The other coefficients are qualitatively similar to the previous models, as long as they are statistically significant. Along with turnover, the share of fixed-term employees, the existence of a works council and an expected turnover increase are statistically insignificant in Western Germany. With fixed and convex, asymmetric adjustment

\footnotetext{
${ }^{35}$ The insignificant results for turnover can be due to banks and insurances where turnover cannot be measured in the standard way. But a robustness check without this sector does not lead to a statistically significant effect of turnover (results are available on request).
} 
costs, the effect of modern technology is statistically significant for Western German plants. Apart from turnover, also the statistical significance of the share of fixed-term employees (now insignificant) and an expected turnover increase (now statistically significant) also change compared to the model with symmetric convex or asymmetric convex in Eastern Germany.

Coming back to the question whether the adjustment costs are purely convex or fixed and convex, I have no straightforward test to answer this question. Yet, my analysis gives me some important hints in favor of a fixed and convex specification. First of all, the selection terms are statistically significant in Western and Eastern Germany meaning that selection in the state of employment adjustment plays a role. Furthermore, a model with fixed and convex costs has a higher predictive power (Theil $\mathrm{U}$ statistic). ${ }^{36} \mathrm{I}$ also find a higher predictive power assuming pure convex costs if the model is estimated just for plants which actually adjust employment. However, if only these plants are considered, the selection term has to be included, resulting in my model with fixed and convex adjustment costs. Based on all this evidence I prefer a fixed and convex specification instead of a pure convex one. The result of asymmetric adjustment costs does not depend on the assumption of purely convex or fixed and convex cost structure. ${ }^{37,38}$

Table 5 summarizes the main results for the adjustment coefficient and elasticities of the several models in this study. As mentioned already, the values are in line with previous studies for Germany such as Addison and Teixeira (2005), Bellmann and Pahnke (2006), Bohachova et al. (2011), Breitung (1992), Buch and Lipponer (2010), Flaig and Rottmann (2001), Flaig and Steiner (1989), Franz and König (1986), Fuchs (2010), Koellreuter (1980), Kölling (1998), Pfeiffer (1999) as well as Rottmann and Ruschinski (1998). These studies differ in database, observation period, observed regions, analyzed sectors, estimation approaches and the specification of adjustment costs. While Flaig and Rottmann (2001), Flaig and Steiner (1989), Koellreuter (1980), as well as Pfeiffer (1999) use a static estimation approach, other studies employ a dynamic approach.

\footnotetext{
${ }^{36}$ Note that the Theil $\mathrm{U}$ statistic is used as a measure for the predictive power in the same way as in the analysis of the model with purely convex adjustment costs.

${ }^{37}$ I also estimate the models separately for the production and the service sector (results are available on request). Both estimations indicate fixed and convex, asymmetric adjustment costs. Furthermore, the elasticities for turnover and wage in the production sector are in line with Flaig and Rottmann (2001) as well as Pfeiffer (1999).

${ }^{38}$ The functional form of firms' adjustment costs varies with plant size. While I also prefer a fixed and convex, asymmetric specification for smaller plants (less than 100 employees), the results of an empirical analysis for bigger plants (100 and more employees) indicate that adjustment costs are characterized by a purely convex, asymmetric structure (results are available on request). This is in line with the results of Del Boca and Rota (1998) for Italy.
}

My study is the only existing one apart from Kölling (1998) that allows for asymmetric adjustment costs. In addition, it extends the sparse literature analyzing dynamic labor demand models for eastern Germany by Fuchs (2010) and by Pfeiffer (1999).

\section{Changing adjustment behavior over time}

Our observation period from 1996 to 2010 contains two business cycles and thus several economic up- and downturns. ${ }^{39}$ The first cycle comprises the years 1996 to 2003 and the second one starts in 2004. With these two cycles it is possible to investigate whether firms' adjustment behavior has changed over time. For such an analysis I need to compare entire business cycles instead of single years. If two single years are compared, these two years could originate from different economic phases of the business cycle. This may lead to a comparison of employment adjustment in economic upturn (predominantly hirings) with that in economic downturns (predominantly firings). This could result in a difference in the estimated effects caused by asymmetry and not just because of a changing over time.

I find evidence for a change in adjustment behavior of German plants in several studies. The German Council of Economic Experts compares firms' adjustment behavior and the labor market reaction of three different economic upturns (1993II-1995II; 1999II-2001I; 2004IV-2007II). Their results indicate a change in the adjustment of employment. Especially in the last upturn the economic recovery was employment-intensive and many full-time jobs covered by social security were created (see GCEE 2007, items 482 492). The flexibility and the dynamic of the labor market increased, which was-among other things-the result of labor market reforms in the years 2003 to 2005. This is also found by Gartner and Klinger (2010), who compare the economic upturns 1998II-2001I and 2004IV-2008I as well as the economic downturns 2001II-2004III and 2008II2010II. Furthermore, they find a lower turnover rate of employment in the second business cycle (see Gartner and Klinger 2010, p. 729). A change towards a lower fluctuation in the number of employees is also found by Burda and Hunt (2011) who compare the recession 2008-2009 with previous ones, Herzog-Stein and Seifert (2010) who compare the recession 2008-2009 with the recession 19731975, as well as Rothe (2009) who compares the upturns

\footnotetext{
${ }^{39}$ In Germany, no clear definition and scheduling of economic phases exists. For that reason there is no comprehensive classification of the years 1996 to 2010. Based on the development of the GDP, the Ifo Business Climate Index and findings of the German Council of Economic Experts as well as the Federal Statistical Office I apply the following classification: 1996-2000, 2004-2007 and 2010 upturns; 20012003 and 2008-2009 downturns.
} 
Table 5 Overview of the main results of several models

\begin{tabular}{|c|c|c|c|c|c|}
\hline Model & Data & $\begin{array}{l}\text { Specification } \\
\text { of the } \\
\text { adjustment } \\
\text { costs }\end{array}$ & $\begin{array}{l}\text { Adjustment } \\
\text { coefficient } \\
\left(\alpha_{1}\right)\end{array}$ & $\begin{array}{l}\text { Wage elasticity } \\
\text { (short-/long-term) }\end{array}$ & $\begin{array}{l}\text { Turnover elasticity } \\
\text { (short-/long-term) }^{\mathrm{a}}\end{array}$ \\
\hline \multirow[t]{2}{*}{ Table 2} & Western Germany; 1996-2010 & $\begin{array}{l}\text { convex and } \\
\text { symmetric }\end{array}$ & 0.675 & $-0.09 /-0.27$ & $0.03 / 0.10$ \\
\hline & Eastern Germany; 1996-2010 & $\begin{array}{l}\text { convex and } \\
\text { symmetric }\end{array}$ & 0.660 & $-0.08 /-0.23$ & $0.02 / 0.07$ \\
\hline \multirow[t]{4}{*}{ Table 3} & Western Germany; 1996-2010 & convex and asymmetric & $0.653^{\mathrm{b}}$ & $-0.05 /-0.15^{\mathrm{b}}$ & $(0.04 / 0.12)^{\mathrm{b}}$ \\
\hline & & & $0.728^{\mathrm{c}}$ & $-0.05 /-0.20^{\mathrm{c}}$ & $(0.01 / 0.04)^{\mathrm{c}}$ \\
\hline & Eastern Germany; 1996-2010 & convex and asymmetric & $0.674^{\mathrm{b}}$ & $-0.01 /-0.04^{b}$ & $(0.03 / 0.11)^{\mathrm{b}}$ \\
\hline & & & $0.754^{\mathrm{c}}$ & $-0.06 /-0.34^{\mathrm{c}}$ & $(0.01 / 0.03)^{\mathrm{c}}$ \\
\hline \multirow[t]{4}{*}{ Table 4} & Western Germany; 1996-2010 & fix, convex and asymmetric & $0.725^{\mathrm{b}}$ & $-0.05 /-0.19^{b}$ & $(0.02 / 0.06)^{\mathrm{b}}$ \\
\hline & & & $0.787^{\mathrm{c}}$ & $-0.09 /-0.43^{\mathrm{c}}$ & $(-0.01 /-0.02)^{\mathrm{c}}$ \\
\hline & Eastern Germany; 1996-2010 & fix, convex and asymmetric & $0.675^{\mathrm{b}}$ & $-0.03 /-0.12^{\mathrm{b}}$ & $(0.02 / 0.09)^{\mathrm{b}}$ \\
\hline & & & $0.749^{c}$ & $-0.10 /-0.76^{\mathrm{c}}$ & $(0.02 / 0.14)^{\mathrm{c}}$ \\
\hline
\end{tabular}

${ }^{\text {a }}$ Statistically insignificant elasticities are in parenthesis

${ }^{b}$ Plants with an employment increase

${ }^{c}$ Plants with an employment decrease

Source: IAB Establishment Panel, waves 1996-2010; own calculations
1998I-2002IV, 2006I-2008II and the downturns in between. Apart from less adjustment activity with respect to the number of employees, a greater adjustment of working hours can be discovered due to better flexibility (see Burda and Hunt 2011), although the instrument of working time adjustment was also used in previous recessions (see Herzog-Stein and Seifert 2010, pp. 553-555).

All in all, there is clear evidence of changing adjustment behavior. But except for Burda and Hunt (2011) who also compare current employment levels with predicted ones, all the studies mentioned above use descriptive analyses of aggregated data. In contrast, I apply an econometric approach with establishment data. Using the dynamic labor demand model from Sect. 5 with fixed, convex, and asymmetric adjustment costs, I analyze a possible change in adjustment behavior. I do so by interacting the lagged logarithmic number of employees covered by social security with a dummy variable indicating whether the observation is from the first business cycle from 1996 to 2003. I restrict the interaction on the lagged logarithmic number of employees covered by social security and interact not all regressor variables because a possible change in firms' labor demand, which would be analyzed in case of interacting all regressor variables, is not part of this analysis. This paper rather focuses on a possible change in adjustment behavior reflected by the adjustment speed. ${ }^{40}$

\footnotetext{
${ }^{40}$ Although it is not in the focus of this analysis, I also estimated the model which contains interactions of all regressor variables with the
}

Table 6 reports the results of this estimation. The interaction term is significantly positive in both Western and Eastern Germany. Based on the coefficients, the median adjustment of Western German plants is approximately 0.14/0.22 years (employment increase/employment decrease) larger in the first business cycle compared with the second business cycle. The corresponding values are $0.22 / 0.34$ years for Eastern Germany. Compared with the analysis without interaction term (see Table 4), a few differences can be found. The coefficients for adjustment, $\alpha_{1}$, are lower if the interaction term is included. Furthermore, the short-run elasticity of labor demand with regard to wage rate has decreased in Western Germany. The statistical significance level for the coefficients has changed only marginally, except for the dummy variable for the modern production technology in Eastern Germany that is now insignificant.

These differences in firms' adjustment behavior between the business cycles can also be found in an analysis with pure convex, symmetric or asymmetric adjustment costs (results are available on request). ${ }^{41}$ Thus, the assumption on the functional form does not drive this result. The employment

dummy variable indicating whether the observation is from the first business cycle (results are available on request). However, these interactions are not jointly statistically significant. Thus, this result strengthens my decision to restrict the interaction on the lagged logarithmic number of employees covered by social security.

${ }^{41}$ In Western Germany the interaction term is only statistically significant in the analysis with pure convex, symmetric adjustment costs if year dummies are not considered in the analysis. 
Table 6 Estimation of the basic model of dynamic labor demand with fix, convex and asymmetric adjustment costs allowing for different adjustment behavior in different business cycles $^{\mathrm{a}}$ (only private plants which adjust their level of employment; 1996-2010; two-step GMMSYS estimator; dependent variable is log number of employees covered by social security)

\begin{tabular}{|c|c|c|c|c|}
\hline \multirow[t]{2}{*}{ Explanatory variables } & \multicolumn{2}{|c|}{ Western Germany } & \multicolumn{2}{|l|}{ Eastern Germany } \\
\hline & coeff. & std.error & coeff. & std.error \\
\hline Lagged employment $l_{t-1}$ & $0.7210^{* * *}$ & 0.0454 & $0.6831^{* * *}$ & 0.0585 \\
\hline$l_{t-1} \times \operatorname{dummy}(1=L$ increased between $t-1$ and $t)$ & $-0.0626^{* * *}$ & 0.0092 & $-0.0771^{* * *}$ & 0.0161 \\
\hline$l_{t-1} \times$ dummy $(1=$ obs. from $1996-2003)$ & $0.0221^{* * *}$ & 0.0035 & $0.0424^{* * *}$ & 0.0090 \\
\hline Turnover $(\log )$ & 0.0170 & 0.0190 & 0.0505 & 0.0402 \\
\hline Nom. wage bill per employee (log) & $-0.0685^{* * *}$ & 0.0172 & $-0.1021^{* * *}$ & 0.0257 \\
\hline Share of female employees (in percent) & 0.0003 & 0.0006 & -0.0001 & 0.0011 \\
\hline Share of qualified employees (in percent) & $-0.0014^{* * *}$ & 0.0003 & $-0.0013^{* * *}$ & 0.0005 \\
\hline Share of part-time employees (in percent) & $0.0010^{* *}$ & 0.0004 & $0.0015^{* *}$ & 0.0006 \\
\hline Share of fixed-term employees (in percent) & 0.0004 & 0.0008 & 0.0007 & 0.0008 \\
\hline Share of employees covered by social security (in percent) & $0.0159^{* * *}$ & 0.0010 & $0.0182^{* * *}$ & 0.0021 \\
\hline Profit situation $\ddagger($ dummy: very good/good $=1)$ & $0.0173^{* * *}$ & 0.0052 & $0.0380^{* * *}$ & 0.0095 \\
\hline Modern production technology (dummy: 1 or 2 on 5-point scale $=1)$ & $0.0136^{* *}$ & 0.0057 & 0.0201 & 0.0130 \\
\hline Works council $\ddagger($ dummy: yes $=1$ ) & -0.0133 & 0.0172 & -0.0242 & 0.0282 \\
\hline Covered by collective agreement $\ddagger$ (dummy: yes $=1)$ & -0.0062 & 0.0113 & -0.0005 & 0.0127 \\
\hline Firm expects turnover increase (dummy: yes $=1$ ) & 0.0050 & 0.0051 & $0.0200^{*}$ & 0.0106 \\
\hline Firm expects turnover reduction (dummy: yes $=1$ ) & $-0.0315^{* * *}$ & 0.0049 & $-0.0464^{* * *}$ & 0.0097 \\
\hline Constant & -0.0809 & 0.4241 & $-1.0865^{* *}$ & 0.4894 \\
\hline Industry dummies & yes & & yes & \\
\hline Year dummies & yes $^{* * *}$ & & yes $^{* * *}$ & \\
\hline Selection term & yes $^{* * *}$ & & yes $^{* *}$ & \\
\hline Other interactions with dummy $(1=L$ increased between $t-1$ and $t)$ & yes $^{* * *}$ & & yes $^{* * *}$ & \\
\hline Number of observations (plant-years) & 28824 & & 17577 & \\
\hline Wald $(74 / 71)$ & $4568.55^{* * *}$ & & $11215.95^{* * *}$ & \\
\hline Hansen $(103 / 100)$ & $265.3168^{* * *}$ & & $250.9633^{* * *}$ & \\
\hline Arellano-Bond (m1 I m2) & $-5.63^{* * *}$ & 0.43 & $-6.67^{* * *}$ & 1.22 \\
\hline
\end{tabular}

${ }^{a}$ The table presents coefficients and standard errors that are calculated from a bootstrapping with 150 replications. Reference categories of the dummy variable groups: no turnover change expected, agriculture and forestry, 1996 and 1997 (Eastern Germany: additional 1998 and 1999). Significance levels: ${ }^{*} p<0.1 ;{ }^{* *} p<0.05$; ${ }^{* * *} p<0.01$. In order to avoid a correlation with the error term, I use $l_{t-2}$ instead of $l_{t-1}$ for the interaction. The model for Eastern Germany is estimated with two lags to get an Arellano-Bond-Test which does not indicate second-order serial correlation in the first-differenced residuals. Arellano-Bond $(\mathrm{m} 1 \mid \mathrm{m} 2)$ are tests for first- and second-order serial correlation in the first differenced residuals. $¥$ Indicates that the information refers to the previous year

Source: IAB Establishment Panel, waves 1996-2010

adjustment in the second business cycle proceeds at a higher speed. ${ }^{42}$ The plants spread the adjustment over a shorter period of time as it is indicated by the lower median adjustment. This might be evidence of lower adjustment costs. A higher flexibility in the adjustment of employment can be a reason for that. However, my results contrast with stud-

\footnotetext{
${ }^{42}$ Strictly speaking a third business cycle starts with the year 2010 . Therefore, the analysis is repeated excluding the year 2010 (results are available on request). The results do not change. An analysis without the year 2010 also indicates a faster adjustment in the second business cycle.
}

ies mentioned above based on a descriptive analysis of aggregated data. These studies find a lower fluctuation in recent years. An explanation might be that some plants adjust with a higher speed and at the same time fewer plants decide to adjust at all. But this explanation is not tenable in light of the analysis with assumed pure convex and asymmetric adjustment costs because all plants, adjusting or not, are included. Fewer plants with employment adjustment in the second cycle would lead to a negative interaction term which I do not observe. Still, there is an explanation for the differences between the results of my study and the results of the studies mentioned above. The opportunity of work- 
ing time adjustment improved over time as a result, for example, of the increased use of working time accounts (see Burda and Hunt 2011, p. 299). As this has made working time adjustment easier, less adjustment of the number of employees is needed. However, once plants have to adjust employment, they now adjust more quickly because the possibility of employment adjustment has also improved in the course of several labor market reforms (see Herzog-Stein and Seifert 2010, p. 552).

In addition to better opportunities for working time adjustment ${ }^{43}$, there are also changes of other labor market institutions which affect firms' adjustment behavior and therefore may explain the empirical result of a faster adjustment. In 2004 the firm-size threshold of the German dismissal protection law was increased from 5 to 10 employees (in the legal sense of the German dismissal protection law). The result was decreased dismissal protection for employees in firms with size of 10 and less, although incumbent employees in these firms still had their prior dismissal protection (see Bauernschuster 2013, p. 296). Less dismissal protection results in decreased dismissal costs for these small firms which should lead to a faster adjustment of the number of employees. This can also explain the higher adjustment speed in the second business cycle. But it is not totally convincing. The dismissal protection just changed for firms with 6 to 10 employees whereas there were no changes for the bulk of firms. Furthermore, empirical evidence for Germany does not show unambiguously that less dismissal protection leads to more and faster employment adjustment (see, e.g., Abraham and Houseman 1994; Bauer et al. 2007; Buechtemann 1993; Schramm and Endemann 2010). Moreover, a robustness check without small plants (less than 30 employees) shows that the change in adjustment speed is not due to small plants. ${ }^{44}$ If only bigger plants are considered in the analysis, the interaction term is also statistically significant and thus indicates a change in adjustment speed. Therefore, the change in dismissal protection cannot explain the increased adjustment speed.

Changes in collective bargaining might additionally explain the empirical results. Since the middle of the 1990s there is a decline in collective agreement coverage in Germany observable (see Ellguth and Kohaut 2011b, p. 245). As some aspects of collective agreements (such as severance pay and specific employment protection) result in higher adjustment costs, the decline of collective agreement coverage leads to lower adjustment costs. This could explain the higher adjustment speed since the coverage rate of sectoral bargaining was on average 9 percentage points lower

\footnotetext{
${ }^{43}$ The empirical relevance of this explanation cannot be checked because the data set does not provide clear information about working hours.

${ }^{44}$ Results are available on request.
}

in the second business cycle. However, an empirical investigation whether plants without a collective agreement adjust their employment more quickly shows no statistical significant effect of a collective agreement on adjustment speed. ${ }^{45}$ Therefore, the decline of collective agreement coverage cannot explain the increased adjustment speed either.

Another change regarding collective bargaining in Germany is the increased use of collective opening clauses which relate to different aspects of the sectoral collective agreements (see Brändle et al. 2011; Kohaut and Schnabel 2007). Some clauses lead to more flexibility in working time adjustment and have the same effects on firms' adjustment behavior as improved opportunity of working time adjustment in general. But opening clauses also increase the flexibility of wages. Therefore, a firm can adjust wages instead of adjusting the number of employees to improve profits in a bad economic situation. Although this an explanation for the results of the mentioned studies using aggregated data, it does not lead to a faster adjustment of the number of employees. However, the increased use of opening clauses started in the middle of the 1990s and is thus not specific to the second business cycle.

Firms' adjustment behavior is also affected by changes in temporary agency employment. Since the reform of the Temporary Employment Agencies Act (Arbeitnehmerüberlassungsgesetz) in 2003 the use of temporary agency employment is eased for plants and the number of temporary agency employees has increased (see, e.g., Antoni and Jahn 2009; Hirsch and Müller 2012). Temporary agency employment is an alternative instrument for the adjustment of firms' labor volume. If it is easier to use temporary agency employment, less adjustment of the number of employees covered by social security is needed. This can also explain the aggregate results, but should not directly affect the adjustment speed.

These considerations suggest that some of the changes of labor market institutions in Germany can explain the aggregate picture of less adjustment of the number of employees but not directly the increased adjustment speed. However, the faster adjustment can indirectly be the result of the institutional changes. Most of these changes imply that less adjustment of the number of employees is needed so that the firms do not have to hire and dismiss so many people at once. The results are lower (convex) adjustment costs due to the convexity of adjustment costs. Moreover, if only a few employees are affected, the works council may not interfere strongly in the dismissal, which again decreases adjustment costs. These various kinds of lower costs result in a faster adjustment of the number of employees.

\footnotetext{
${ }^{45}$ Results are available on request.
} 


\section{Conclusions}

Using a large and representative establishment data set for Germany, I investigate firms' labor adjustment behavior in terms of the number of employees covered by social security. The results of my empirical analysis indicate that adjustment costs are characterized by a convex structure including a fixed component. Thus firms do not adjust employment permanently, and there are periods with no employment adjustment. Furthermore, the cost structure is found to be asymmetric: In case of an employment increase, the adjustment runs faster compared with a decrease suggesting that dismissal costs exceed the costs of hiring. These results are in line with the existing literature. Based on my preferred baseline model the long-term wage elasticity is -0.19 in case of an employment increase and -0.43 in case of an employment decrease in Western Germany. The corresponding values are -0.12 and -0.76 for Eastern Germany. Thus the elasticities are higher (in absolute terms) in case of a reduction in employment.

Moreover, I identify a change in firms' employment adjustment over time. The adjustment was spread over a longer period of time in the business cycle from 1996 to 2003 and thus the adjustment speed was lower compared to the following business cycle from 2004 to 2010. This indicates lower adjustment costs in the business cycle after 2003, which might be related to recent reforms and more flexibility in the labor market (e.g., better opportunities for working time adjustment, easier use of temporary agency employment). Nowadays, the plants seem to be able to adjust their employment covered by social security more quickly.

For a further investigation of labor adjustment, I would need information on working time to include this adjustment dimension in the analysis, thus providing a more complete picture of firms' labor adjustment. Several studies have shown an intensified use of working time adjustment in the recent past, which may also affect the change in the adjustment of the number of employees. Because of recent reforms of temporary agency employment in Germany, this type of employment may have become more important for firms' employment adjustment. The faster adjustment of the employment covered by social security in the second business cycle found in this study may reflect this, among other things. Future research should thus take temporary agency employment explicitly into account and analyze its role as an alternative adjustment instrument.

\section{Executive summary}

Over the business cycle, firms have to adjust their labor volume. This employment adjustment causes adjustment costs, which firms have to take into account. Their adjustment behavior depends on the functional form of these adjustment costs. One can distinguish three basic specifications: fixed, linear and convex. A combination of these specifications is also possible and in the existing literature there is a predominance of such a combined structure for adjustment costs. However, this has not been shown to extend to Germany yet. Furthermore, adjustment costs are asymmetric. Studies show for Germany that dismissal costs exceed hiring costs.

There are no direct data on firms' adjustment costs available for Germany. Thus, I use a dynamic labor demand model for the analysis of the functional form of firms' adjustment costs in Germany. I compare a pure convex specification for adjustment costs with a combination of a fixed and a convex structure. The data used for the analysis are the waves 1996 until 2010 of the IAB Establishment Panel. Because of limitations in data, the empirical investigation can only analyze the adjustment of the number of employees and has to neglect the working time dimension. Moreover, only the number of employees covered by social security are considered.

The descriptive results show that every year plants increase or decrease employment, regardless of the business cycle phase. However, more than 50 percent of the plants do not change their employment level over the year. Furthermore, there is a first evidence in favor of non-convex adjustment costs. Conducting a dynamic panel analysis and a switching regression, my empirical analysis provide further evidence in favor of non-convex adjustment costs. Although there is no straightforward test to answer the question whether the adjustment costs are purely convex or fixed and convex, my analysis gives me some important hints in favor of a fixed and convex specification. Moreover, the empirical results indicate asymmetric adjustment costs in Germany with dismissal costs exceeding the costs of hiring.

Furthermore, I investigate whether firms' adjustment behavior has changed over time between 1996 and 2010. Several studies for Germany have shown that labor market flexibility increased and the turnover rate of employment decreased over time. Besides less adjustment activity with regard to the number of employees, a greater adjustment of working time can be discovered. There is a clear evidence of changing adjustment behavior, but the previous studies contain only descriptive analyses of aggregated data. In contrast, I use an econometric approach with establishment data. The results show that the adjustment speed increased over time. Plants adjust their employment covered by social security more quickly in the business cycle from 2004 to 2010 compared to the previous business cycle from 1996 to 2003. This indicates lower adjustment costs in the business cycle after 2003, which might be related to recent reforms and more flexibility in the labor market (e.g., better opportunities for working time adjustment, easier use of temporary agency employment). 
Future research should take the working time dimension into account if data provide this information. This would result in a more complete picture of firms' labor adjustment. One should also consider temporary agency employment explicitly and analyze its role as an alternative adjustment instrument.

\section{Kurzfassung}

Ein Betrieb muss im Konjunkturverlauf immer wieder seine Beschäftigung anpassen. Bei dieser Anpassung fallen Kosten an, die der Betrieb zu berücksichtigen hat. Dabei wird das genaue Anpassungsverhalten der Betriebe durch die funktionale Form der Anpassungskosten bestimmt. Es lassen sich drei Grundformen unterscheiden: fix, linear und konvex. Darüber hinaus ist auch eine Kombination der drei Grundformen möglich. Ergebnis früherer Studien ist, dass solch eine kombinierte Struktur für die betrieblichen Anpassungskosten zu präferieren ist. Dieses konnte jedoch noch nicht für Deutschland gezeigt werden. Des Weiteren sind die Anpassungskosten asymmetrisch, wobei sich für Deutschland zeigt, dass die Entlassungskosten größer sind als die Einstellungskosten.

Für Deutschland sind keine direkten Daten für die betrieblichen Anpassungskosten verfügbar. Aus diesem Grund erfolgt die Analyse auf Basis eines Modells der dynamischen Arbeitsnachfrage. Dazu werden zwei Modelle untersucht, das eine basiert auf der Annahme rein konvexer Anpassungskosten und für das andere wird ein fixe und konvexe Spezifikation angenommen. Dabei wird überprüft, welches Modell zu präferieren ist. Die Basis für die empirische Analyse ist das IAB-Betriebspanel, aus dem die Beobachtungen der Jahre 1996 bis 2010 verwendet werden. Der Datensatz enthält jedoch keine belastbaren Informationen zur Arbeitszeit, so dass nur eine Anpassung der Zahl der Beschäftigten berücksichtigt wird. Außerdem werden nur die sozialversicherungspflichtig Beschäftigten betrachtet.

Ein Ergebnis der deskriptiven Analyse ist, dass es in jedem Jahr unabhängig von der aktuellen konjunkturellen Lage Betriebe gibt, die ihre Beschäftigung erhöhen oder verringern. Darüber hinaus passen aber mehr als 50 Prozent der Betriebe jedes Jahr ihre Beschäftigungshöhe nicht an. Außerdem gibt es erste Hinweise für die Existenz nichtkonvexer Anpassungskosten. Die empirischen Ergebnisse, die von dynamischen Panelschätzungen und SwitchingRegressionen stammen, beinhalten ebenfalls Indizien dafür, dass nicht-konvexe Anpassungskosten relevant sind. Für die Beantwortung der Frage, ob das Modell basierend auf der Annahme rein konvexer Anpassungskosten oder das Modell basierend auf einer kombinierten Kostenstruktur zu präferieren ist, existiert allerdings kein eindeutiger Test. Aber mehrere konkrete Hinweise deuten darauf hin, dass die funk- tionale Form der Anpassungskosten eher durch Kombination von einer fixen und einer quadratischen Komponente gegeben ist. Außerdem zeigen die Ergebnisse, dass die betrieblichen Anpassungskosten asymmetrisch sind mit Entlassungskosten, die die Einstellungskosten übersteigen.

Des Weiteren erfolgt eine Untersuchung, ob sich das betriebliche Anpassungsverhalten im Zeitverlauf von 1996 bis 2010 verändert hat. Frühere Studien für Deutschland zeigen, dass der Arbeitsmarkt in den letzten Jahren flexibler geworden ist. Die Fluktuation der Beschäftigung hat jedoch abgenommen. Während es in den letzen Jahren eine vermehrte Anpassung der Arbeitsstunden gab, wurde eine Anpassung der Zahl der Beschäftigten nur in einem geringeren Maße vorgenommen. Insgesamt deutet die bisherige empirische Evidenz auf unterschiedliche Anpassungsverhalten in den verschiedenen Konjunkturzyklen hin. Diese Evidenz beruht jedoch nur auf deskriptiven Analysen aggregierter Daten. Im Gegensatz dazu, werden in dieser Arbeit disaggregierte Betriebsdaten empirisch untersucht. Es zeigt sich eine $\mathrm{Zu}$ nahme der Anpassungsgeschwindigkeit. Die Betriebe haben die Zahl ihrer sozialversicherungspflichtig Beschäftigten im zweiten beobachteten Konjunkturzyklus von 2004 bis 2010 schneller angepasst als im ersten Zyklus von 1996 bis 2003. Dieses deutet auf geringere betriebliche Anpassungskosten im Konjunkturzyklus nach 2003 hin. Als Begründung für diese Entwicklung kommen u.a. Reformen am deutschen Arbeitsmarkt in Betracht, die die Möglichkeiten zur Arbeitszeitanpassung und den Einsatz von Leiharbeit betreffen.

Gegenstand zukünftiger Forschung sollte die betriebliche Anpassung der Arbeitszeit sein, sofern es es die Datengrundlage ermöglicht. Damit wären konkrete Aussagen über die betriebliche Anpassung des gesamten Arbeitsvolumens möglich. Des Weiteren sollte man auch die Leiharbeit berücksichtigen und deren Rolle als alternative Möglichkeit zur Beschäftigungsanpassung untersuchen. 


\section{Appendix}

Table 7 Summary statistics

\begin{tabular}{|c|c|c|c|c|}
\hline \multirow[t]{2}{*}{ Variables } & \multicolumn{2}{|c|}{ Western Germany } & \multicolumn{2}{|c|}{ Eastern Germany } \\
\hline & mean & std.dev. & mean & std.dev. \\
\hline Turnover $(\log )$ & 15.0067 & 2.3580 & 14.1643 & 1.9656 \\
\hline Nom. wage bill per employee (log) & 7.4273 & 0.6565 & 7.1740 & 0.5757 \\
\hline Share of female employees (in percent) & 37.5478 & 28.7271 & 36.0627 & 29.8497 \\
\hline Share of qualified employees (in percent) & 71.3128 & 26.2142 & 82.9504 & 22.0685 \\
\hline Share of part-time employees (in percent) & 19.2782 & 22.7839 & 12.8306 & 20.6617 \\
\hline Share of fixed-term employees (in percent) & 3.5216 & 9.3177 & 4.5019 & 12.3852 \\
\hline Share of employees covered by social security (in percent) & 79.9109 & 22.3018 & 83.7581 & 19.2358 \\
\hline Profit situation $\ddagger($ dummy: very good/good $=1)$ & 0.3381 & 0.4731 & 0.3596 & 0.4799 \\
\hline Modern production technology (dummy: 1 or 2 on 5-point scale $=1)$ & 0.6689 & 0.4706 & 0.6730 & 0.4691 \\
\hline Works council $\ddagger($ dummy: yes $=1)$ & 0.3349 & 0.4720 & 0.2199 & 0.4142 \\
\hline Covered by collective agreement $\ddagger$ (dummy: yes $=1)$ & 0.5863 & 0.4926 & 0.3863 & 0.4869 \\
\hline Firm expects turnover increase (dummy: yes $=1$ ) & 0.2809 & 0.4494 & 0.2218 & 0.4154 \\
\hline Firm expects turnover reduction (dummy: yes $=1$ ) & 0.2527 & 0.4346 & 0.2736 & 0.4458 \\
\hline Employment adjustment (dummy: yes $=1$ ) & 0.6632 & 0.4726 & 0.6389 & 0.4803 \\
\hline
\end{tabular}

Notes: Unweighted data, private sector only. $¥$ Indicates that the information refers to the previous year

Source: IAB Establishment Panel, waves 1996-2010 
Table 8 Estimation of the selection model $^{\text {a }}$ (only private plants; $1996 / 7-2010^{\text {b }}$; probit estimator ${ }^{\mathrm{c}}$; dependent variable is a dummy variable whether the plant adjusts the number employees covered by social security from period $t-1$ to period $t$ )

\begin{tabular}{|c|c|c|c|c|}
\hline \multirow[t]{2}{*}{ Explanatory variables } & \multicolumn{2}{|c|}{ Western Germany } & \multicolumn{2}{|c|}{ Eastern Germany } \\
\hline & coeff. & std.error & coeff. & std.error \\
\hline$l_{t-2}$ & $0.5464^{* * *}$ & 0.0075 & $0.5627^{* * *}$ & 0.0086 \\
\hline I $\Delta$ Turnoverl (absolute percentage change) & 0.0000 & 0.0000 & $0.0003^{*}$ & 0.0001 \\
\hline $\mid \Delta$ Nom. wage bill per employeel (absolute percentage change) & $0.0004^{* *}$ & 0.0002 & 0.0001 & 0.0002 \\
\hline $\mid \Delta$ Share of female employeesI (absolute change in percentage points) & $0.0047^{* * *}$ & 0.0010 & $-0.0092^{* * *}$ & 0.0012 \\
\hline $\mid \Delta$ Share of qualified employeesI (absolute change in percentage points) & 0.0008 & 0.0005 & $0.0013^{* *}$ & 0.0006 \\
\hline $\mid \Delta$ Share of part-time employeesl (absolute change in percentage points) & $-0.0019^{* * *}$ & 0.0006 & $-0.0031^{* * *}$ & 0.0009 \\
\hline $\mid \Delta$ Share of fixed-term employeesl (absolute change in percentage points) & $0.0066^{* * *}$ & 0.0012 & $0.0060^{* * *}$ & 0.0013 \\
\hline I $\Delta$ Share of employees covered by social securityl (absolute change in percentage points) & $0.0805^{* * *}$ & 0.0027 & $0.0776^{* * *}$ & 0.0039 \\
\hline Profit situation $\ddagger($ dummy: very good/good $=1)$ & $0.0356^{*}$ & 0.0185 & $0.0740^{* * *}$ & 0.0207 \\
\hline Improvement of the profit situation (dummy: yes $=1$ ) & 0.0024 & 0.0185 & $-0.0557^{* * *}$ & 0.0208 \\
\hline Deterioration of the profit situation (dummy: yes $=1$ ) & $0.0539^{* * *}$ & 0.0184 & 0.0139 & 0.0203 \\
\hline (dummy: 1 or 2 on 5 -point scale $=1$ ) & -0.0153 & 0.0180 & -0.0051 & 0.0200 \\
\hline Improvement of the production technology (dummy: yes $=1$ ) & -0.0050 & 0.0205 & -0.0233 & 0.0226 \\
\hline Deterioration of the production technology (dummy: yes $=1$ ) & 0.0309 & 0.0214 & 0.0080 & 0.0236 \\
\hline Works council $\ddagger($ dummy: yes $=1$ ) & -0.0245 & 0.0255 & -0.0496 & 0.0322 \\
\hline Covered by collective agreement $\ddagger$ (dummy: yes $=1$ ) & $-0.0386^{* *}$ & 0.0179 & -0.0038 & 0.0208 \\
\hline Firm expects turnover increase (dummy: yes $=1$ ) & $0.2761^{* * *}$ & 0.0229 & $0.3063^{* * *}$ & 0.0271 \\
\hline Firm expects turnover reduction (dummy: yes $=1$ ) & $0.2320^{* * *}$ & 0.0231 & $0.2394^{* * *}$ & 0.0249 \\
\hline Change 1 expects turnover (dummy: yes $=1$ ) ${ }^{\mathrm{d}}$ & $-0.1047^{* * *}$ & 0.0215 & $-0.0588^{* *}$ & 0.0239 \\
\hline Change2 expects turnover (dummy: yes $=1)^{\mathrm{e}}$ & $0.0775^{* * *}$ & 0.0213 & $0.0799^{* * *}$ & 0.0230 \\
\hline Constant & $-1.6676^{* * *}$ & 0.0813 & $-1.6786^{* * *}$ & 0.0713 \\
\hline Industry dummies & $\operatorname{yes}^{* * *}$ & & yes ${ }^{* * *}$ & \\
\hline Year dummies & yes & & yes $^{* * *}$ & \\
\hline Number of observations (plant-years) & 45470 & & 34692 & \\
\hline Wald (44) & $9115.50^{* * *}$ & & & \\
\hline Pseudo R-squared & 0.3398 & & & \\
\hline
\end{tabular}

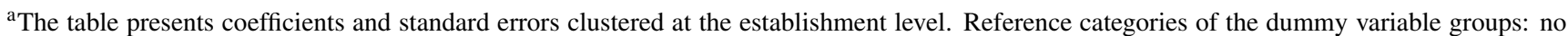
turnover change expected, agriculture and forestry, no change of the profit situation, no change of the production technology, no change of the turnover expectations and 1996. Significance levels: ${ }^{*} p<0.1 ;{ }^{* *} p<0.05 ;{ }^{* * *} p<0.01$. $¥$ Indicates that the information refers to the previous year

${ }^{\mathrm{b}} l_{t-2}$ is only observable for Eastern Germany from 1997 onwards. Therefore, the estimation for Eastern Germany is based on the years 1997 to 2010

${ }^{\mathrm{c}}$ For a converging probit model in Eastern Germany I use an IRLS-Algorithm instead of the default Newton-Raphson-Algorithm. Thus a Wald statistic and the pseudo R-squared are not generated

${ }^{\mathrm{d}}$ The dummy variable reflects a plant expecting a change of the turnover, while expecting no change in the previous period

e The dummy variable reflects a plant expecting no change of the turnover, while expecting a change in the previous period

Source: IAB Establishment Panel, waves 1996/7-2010 


\section{References}

Abowd, J.M., Kramarz, F.: The costs of hiring and separations. Labour Econ. 10(4), 499-530 (2003)

Abraham, K.G., Houseman, S.N.: Does employment protection inhibit labor market flexibility? Lessons from Germany, France, and Belgium. In: Blank, R.M. (ed.) Social Protection versus Economic Flexibility-Is There a Trade-off?, 1st. edn., pp. 59-93. University of Chicago Press, Chicago (1994)

Addison, J.T., Teixeira, P.: Employment adjustment in two countries with poor reputations: analysis of aggregate, firm, and flow data for Portugal and Germany. Int. Econ. Econ. Policy 1(4), 329-348 (2005)

Addison, J.T., Teixeira, P.: The effect of work councils on employment change. Ind. Relat. 45(1), 1-25 (2006)

Anderson, P.M.: Linear adjustment costs and seasonal labor demand: evidence from retail trade firms. Q. J. Econ. 108(4), 1015-1042 (1993)

Antoni, M., Jahn, E.J.: Do changes in regulation affect employment duration in temporary help agencies? Ind. Labor Relat. Rev. 62(2), 226-251 (2009)

Arellano, M., Bond, S.: Some tests of specification for panel data: Monte Carlo evidence and an application to employment equations. Rev. Econ. Stud. 58(2), 277-297 (1991)

Arellano, M., Bover, O.: Another look at the instrumental variable estimation of error-components models. J. Econom. 68(1), 29-51 (1995)

Baltagi, B.H.: Econometric Analysis of Panel Data, 4th. edn. Wiley, Chichester (2008)

Bauer, T.K., Bender, S., Bonin, H.: Dismissal protection and worker flows in small establishments. Economica 74(296), 804-821 (2007)

Bauernschuster, S.: 'Dismissal protection and small firms' hirings: evidence from a policy reform'. Small Bus. Econ. 40(2), 293-307 (2013)

Bellmann, L., Kölling, A.: Betriebliche Bestimmungsgrößen der Beschäftigungsentwicklung für 1997 - Ergebnisse des IABBetriebspanels für West- und Ostdeutschland. Mitt. Arb.marktBerufsforsch. 30(1), 90-101 (1997)

Bellmann, L., Pahnke, A.: Auswirkungen organisatorischen Wandels auf die betriebliche Arbeitsnachfrage. J. Labour Mark. Res. 39(2), 201-233 (2006)

Bellmann, L., Kohaut, S., Lahner, M.: Das IAB-Betriebspanel Ansatz und Analysepotenziale. In: Kleinhenz, G. (ed.) IABKompendium - Arbeitsmarkt- und Berufsforschung, Beiträge zur Arbeitsmarkt- und Berufsforschung Nr. 250, pp. 13-20. Institut für Arbeitsmarkt- und Berufsforschung, Nürnberg (2002)

Bentolila, S., Bertola, G.: Firing costs and labour demand: how bad is eurosclerosis?. Rev. Econ. Stud. 57(3), 381-402 (1990)

Bentolila, S., Saint-Paul, G.: A model of labor demand with linear adjustment costs. Labour Econ. 1(3/4), 303-326 (1994)

Blundell, R., Bond, S.: Initial conditions and moment restrictions in dynamic panel data models. J. Econom. 87(1), 115-143 (1998)

Blundell, R., Bond, S.: GMM estimation with persistent panel data: an application to production functions. Econom. Rev. 19(3), 321340 (2000)

Blundell, R., Bond, S., Windmeijer, F.: Estimation in dynamic panel data models: improving on the performance of the standard GMM estimator. In: Baltagi, B.H. (ed.) Nonstationary Panels, Panel Conintegration, and Dynamic Panels, pp. 53-91. Elsevier, New York (2000)

Bohachova, O., Boockmann, B., Buch, C.M.: Labor demand during the crisis: what happened in Germany?' IZA Discussion Paper No. 6074, Institute for the Study of Labor, Bonn (2011)

Bond, S.: Dynamic panel data models: a guide to micro data methods and practice. Port. Econ. J. 1(2), 141-162 (2002)
Bond, S., van Reenen, J.: Microeconometric models of investment and employment. In: Heckman, J.J., Leamer, E.E. (eds.) Handbook of Econometrics, vol. 6A, pp. 4417-4498. North-Holland, Amsterdam (2007)

Brändle, T., Heinbach, W.D., Maier, M.F.: Tarifliche Öffnung in Deutschland: Ausmaß, Determinanten, Auswirkungen. J. Labour Mark. Res. 44(1/2), 163-172 (2011)

Breitung, J.: Dynamische Modelle für die Paneldatenanalyse. Haag + Herchen Verlag, Frankfurt/Main (1992)

Breitung, J.: Die Arbeitsnachfrage niedersächsischer Industriebetriebe: Eine dynamische Paneldatenanalyse mit Zeitreihenmethoden. In: Hochmuth, U., Wagner, J. (eds.) Firmenpanelstudien in Deutschland - Konzeptionelleüberlegungen und empirische Analysen, pp. 17-38. Francke Verlag, Tübingen (1994)

Bresson, G., Kramarz, F., Sevestre, P.: Dynamic labour demand models. In: Mátyás, L., Sevestre, P. (eds.) The Econometrics of Panel Data-Handbook of Theory and Applications, pp. 360 387. Kluwer Academic Publishers, Dordrecht (1992)

Buch, C.M., Lipponer, A.: Volatile multinationals? Evidence from the labor demand of German firms. Labour Econ. 17, 345-353 (2010)

Buechtemann, C.F.: Employment security and deregulation: the West German experience. In: Buechtemann, C.F. (ed.) Employment Security and Labor Market Behavior-Interdisciplinary Approaches and International Evidence, pp. 272-296. ILR Press, Ithaca (1993)

Burda, M.C.: Monopolistic competition, costs of adjustment, and the behavior of European manufacturing employment. Eur. Econ. Rev. 35, 61-79 (1991)

Burda, M.C., Hunt, J.: What explains the German labor market miracle in the great recession? Brookings Pap. Econ. Act. 42(1), 273-335 (2011)

Burgess, S.M.: Employment adjustment in UK manufacturing. Econ. J. 98(389), 81-103 (1988)

Caballero, R.J., Engel, E.M.R.A., Haltiwanger, J.C.: Aggregate employment dynamics: building from microeconomic evidence. Am. Econ. Rev. 87(1), 115-137 (1997)

Cahuc, P., Zylberberg, A.: Labor Economics. MIT Press, Cambridge (2004)

Cameron, A.C., Trivedi, P.K.: Microeconometrics-Methods and Applications. Cambridge University Press, Cambridge (2005)

Chang, C.-C., Stefanou, S.E.: Specification and estimation of asymmetric adjustment rates for quasi-fixed factors of production. J. Econ. Dyn. Control 12(1), 145-151 (1988)

Cooper, R., Willis, J.L.: The cost of labor adjustment: inference from the gap. Rev. Econ. Dyn. 12(4), 632-647 (2009)

Cooper, R.W., Haltiwanger, J.C., Willis, J.: Dynamics of labor demand: evidence from plant-level observations and aggregate implications. NBER Working Paper 10297, National Bureau of Economic Research, Cambridge (2004)

Del Boca, A., Rota, P.: How much does hiring and firing cost? Survey evidence from a sample of Italian firms. Labour 12(3), 427-449 (1998)

Dolfin, S.: An examination of firms' employment costs. Appl. Econ. 38(8), 861-878 (2006)

Ehrenberg, R.G., Smith, R.S.: Modern Labor Economics, 11th edn. Pearson, Boston (2012)

Ellguth, P., Kohaut, S.: Der Staat als Arbeitgeber: Wie unterscheiden sich die Arbeitsbedingungen zwischen öffentlichem Sektor und der Privatwirtschaft? Ind. Bezieh. 18(1-2), 11-38 (2011a)

Ellguth, P., Kohaut, S.: Tarifbindung und betriebliche Interessenvertretung: Aktuelle Ergebnisse aus dem IAB-Betriebspanel 2010. WSI-Mitt. 64(5), 242-247 (2011b)

Emerson, M.: Regulation or deregulation of the labour market-policy regimes for the recruitment and dismissal of employees in the industrialised countries. Eur. Econ. Rev. 32(4), 775-817 (1988) 
Fischer, G., Janik, F., Müller, D., Schmucker, A.: The IAB establishment panel * things users should know. Schmollers Jahrb. 129(1), 133-148 (2009)

FitzRoy, F.R., Funke, M.: Skills, wages and employment in East and West Germany. Reg. Stud. 32(5), 459-467 (1998)

Flaig, G., Rottmann, H.: Input demand and the short- and long-run employment thresholds: an empirical analysis for the German manufacturing sector. Ger. Econ. Rev. 2(4), 367-384 (2001)

Flaig, G., Steiner, V.: Stability and dynamic properties of labour demand in West-German manufacturing. Oxf. Bull. Econ. Stat. 51(4), 395-412 (1989)

Franz, W.: Arbeitsmarktökonomik, 8th edn. Springer, Berlin (2013)

Franz, W., König, H.: The nature and causes of unemployment in the Federal Republic of Germany since the 1970s: an empirical investigation. Economica 53(210), S219-S244 (1986)

Freeman, R.B., Medoff, J.L.: What do unions do? Basic Books, New York (1984)

Fuchs, M.: Determinanten regionaler Beschäftigungsentwicklung. W. Bertelsmann Verlag, Bielefeld (2010)

Funke, M., Maurer, W., Siddiqui, S., Strulik, H.: The employmentfinancing nexus: evidence from a panel of West German firms. Small Bus. Econ. 11(3), 225-235 (1998)

Garcia, J.R., Jiménez-Martín, S., Labeaga, J.M.: Comparison of estimators in dynamic panel data sample selection and switching models (2007, work in progress)

Gartner, H., Klinger, S.: Verbesserte Institutionen für den Arbeitsmarkt in der Wirtschaftskrise. Wirtschaftsdienst 90(11), 728-734 (2010)

Gavosto, A., Sestito, P.: Turnover costs in Italy: some preliminary evidence. Statistica 53(3), 429-451 (1993)

GCEE: Das Erreichte nicht verspielen, Jahresgutachten 2007/08. German Council of Economic Experts, Wiesbaden (2007)

Goldfeld, S.M., Quandt, R.E.: Techniques for estimating switching regressions. In: Goldfeld, S.M., Quandt, R.E. (eds.) Studies in Nonlinear Estimation, pp. 3-35. Ballinger, Cambridge (1976)

Gorter, C., Hassink, W.H., Russo, G.: The structure of hiring and labour market tightness. Econ. Lett. 80(1), 99-103 (2003)

Goux, D., Maurin, E., Pauchet, M.: Fixed-term contracts and the dynamics of labour demand. Eur. Econ. Rev. 45(3), 533-552 (2001)

Greene, W.H.: Econometric Analysis, 7th edn. Pearson, Boston (2012)

Hall, R.E.: Measuring factor adjustment costs. Q. J. Econ. 119(3), 899927 (2004)

Hamermesh, D.S.: Labor demand and the structure of adjustment costs. Am. Econ. Rev. 79(4), 674-689 (1989)

Hamermesh, D.S.: Aggregate employment dynamics and lumpy adjustment costs. Carnegie-Rochester Conf. Ser. Public Policy 33, 93-130 (1990)

Hamermesh, D.S.: A general model of dynamic labor demand. Rev. Econ. Stat. 74(4), 733-737 (1992)

Hamermesh, D.S.: Labor Demand. Princeton University Press, Princeton $(1993 \mathrm{a})$

Hamermesh, D.S.: Spatial and temporal aggregation in the dynamics of labor demand. In: van Ours, J.C., Pfann, G.A., Ridder, G. (eds.) Labor Demand and Equilibrium Wage Formation, 1st edn., pp. 91-108. North-Holland, Amsterdam (1993b)

Hamermesh, D.S.: Labour demand and the source of adjustment costs. Econ. J. 105(430), 620-634 (1995)

Hamermesh, D.S., Pfann, G.A.: Turnover and the dynamics of labour demand. Economica 63(251), 359-367 (1996)

Heckman, J.J.: Dummy endogenous variables in a simultaneous equation system. Econometrica 46(4), 931-959 (1978)

Herzog-Stein, A., Seifert, H.: Der Arbeitsmarkt in der Großen Rezession - Bewährte Strategien in neuen Formen. WSI-Mitt. 63(11), 551-559 (2010)

Hirsch, B., Müller, S.: The productivity effect of temporary agency work: evidence from German panel data. Econ. J. 122(562), F216-F235 (2012)
Hirsch, B., Schank, T., Schnabel, C.: Works councils and separations: voice, monopoly, and insurance effects. Ind. Relat. 49(4), 566$592(2010)$

Holt, C.C., Modigliani, F., Muth, J.F., Simon, H.A.: Planning Production, Inventories, and Work Force. Prentice-Hall, Englewood Cliffs (1960)

Holtz-Eakin, D., Rosen, H.S.: Municipal labor demand in the presence of uncertainty: an econometric approach. J. Labor Econ. 9(3), 276-293 (1991)

Hunt, J.: Firing costs, employment fluctuations and average employment: an examination of Germany. Economica 67(266), 177-202 (2000)

Jaramillo, F., Schiantarelli, F., Sembenelli, A.: Are adjustment costs for labor asymmetric? An econometric test on panel data for Italy. Rev. Econ. Stat. 75(4), 640-648 (1993)

Jiménez-Martín, S.: Strike outcomes and wage settlements in Spain. Labour 20(4), 673-698 (2006)

Jiménez-Martín, S., Garcia, J.: Initial offers and outcomes in wage bargaining: who wins? Empir. Econ. 39(3), 815-846 (2010)

Jirjahn, U.: Works councils and employment growth in German establishments. Camb. J. Econ. 34(3), 475-500 (2010)

Koellreuter, C.: Recent and prospective trends of the demand for labour in the Federal Republic of Germany: an ex-post analysis and some simulation results with a macro- and linked-industry model. In: Malinvaud, E., Fitoussi, J.-P. (eds.) Unemployment in Western Countries, pp. 321-373. Macmillan, London (1980)

Kohaut, S., Schnabel, C.: Tarifliche Öffnungsklauseln - Verbreitung, Inanspruchnahme und Bedeutung. Soz. Fortschr. 56(2), 33-40 (2007)

Kölling, A.: Anpassungen auf dem Arbeitsmarkt - Eine Analyse der dynamischen Arbeitsnachfrage in der Bundesrepublik Deutschland, Institut für Arbeitsmarkt- und Berufsforschung, Nürnberg (1998)

Kölling, A.: The IAB-establishment panel. Schmollers Jahrb. 120(2), 291-300 (2000)

Kramarz, F., Michaud, M.-L.: The shape of hiring and separation costs in France. Labour Econ. 17(1), 27-37 (2010)

Lapatinas, A.: Labour adjustment costs: estimation of a dynamic discrete choice model using panel data for Greek manufacturing firms. Labour Econ. 16(5), 521-533 (2009)

Lodigiani, E., Salomone, S.: Migration-induced transfers of norms. The case of female political empowerment. Discussion Paper No. 2012-1, Institut de Recherches économiques et Sociales de l'Université catholique de Louvain, Louvain (2012)

Maddala, G.S.: Disequilibrium, self-selection, and switching models. In: Grilichest, Z., Intriligator, M.D. (eds.) Handbook of Econometrics, vol. 3, pp. 1633-1688. North-Holland, Amsterdam (1986)

Maddala, G.S.: Limited-Dependent and Qualitative Variables in Econometrics. Cambridge University Press, Cambridge (1994)

Merkl, C., Wesselbaum, D.: Extensive vs. intensive margin in Germany and the United States: any difference? Appl. Econ. Lett. 18(9), 805-808 (2011)

Muehlemann, S., Pfeifer, H.: The structure of hiring costs in Germany: evidence from firm-level Data. IZA Discussion Paper No. 7656, Institute for the Study of Labor, Bonn (2013)

Müller-Jentsch, W.: Soziologie der industriellen Beziehungen, 2nd edn. Campus Verlag, Frankfurt/Main (1997)

Nickell, S.J.: Fixed costs, employment and labour demand over the cycle. Economica 45(180), 329-345 (1978)

Nickell, S.J.: An investigation of the determinants of manufacturing employment in the United Kingdom. Rev. Econ. Stud. 51(4), 529557 (1984)

Nickell, S.J.: Dynamic models of labor demand. In: Ashenfelter, O., Layard, R. (eds.) Handbook of Labor Economics, vol. 1, pp. 473522. North-Holland, Amsterdam (1986) 
Nilsen, Ø.A., Salvanes, K.G., Schiantarelli, F.: Employment changes, the structure of adjustment costs, and plant size. Eur. Econ. Rev. 51(3), 577-598 (2007)

Nissim, J.: An examination of the differential patterns in the cyclical behaviour of the employment, hours and wages of labour of different skills: British mechanical engineering, 1963-1978. Economica 51(204), 423-436 (1984)

Oi, W.Y.: Labor as a quasi-fixed factor. J. Polit. Econ. 70(6), 538-555 (1962)

Pfann, G.A., Palm, F.C.: Asymmetric adjustment costs in non-linear labour demand models for the Netherlands and U.K. manufacturing sectors. Rev. Econ. Stud. 60(2), 397-412 (1993)

Pfann, G.A., Verspagen, B.: The structure of adjustment costs for labour in the Dutch manufacturing sector. Econ. Lett. 29(4), 365371 (1989)

Pfeiffer, F.: Human capital and innovation in eastern and western Germany. In: Fritsch, M., Brezinski, H. (eds.) Innovation and Technological Change in Eastern Europe-Pathways to Industrial Recovery, pp. 142-166. Edward Elgar, Cheltenham (1999)

Pindyck, R.S., Rotemberg, J.J.: Dynamic factor demand and the effects of energy price shocks. Am. Econ. Rev. 73(5), 1066-1079 (1983a)

Pindyck, R.S., Rotemberg, J.J.: Dynamic factor demands under rational expectations. Scand. J. Econ. 85(2), 223-238 (1983b)

Roodman, D.: How to do xtabond2: an introduction to difference and system GMM in stata. Stata J. 9(1), 86-136 (2009)

Rosen, S.: Short-run employment variation on class-I railroads in the U.S., 1947-1963. Econometrica 36(3/4), 511-529 (1968)

Rota, P.: Estimating labor demand with fixed costs. Int. Econ. Rev. 45(1), 25-48 (2004)

Rothe, T.: Arbeitsmarktentwicklung im Konjunkturverlauf - Nicht zuletzt eine Frage der Einstellung, IAB-Kurzbericht 13/2009, Institute for Employment Research, Nürnberg (2009)

Rothschild, M.: On the cost of adjustment. Q. J. Econ. 85(4), 605-622 (1971)

Rottmann, H., Ruschinski, M.: The labour demand and the innovation behaviour of firms. An empirical investigation for the West German manufacturing firms. Jahrb. Natl.ökon. Stat. 217(6), 741-752 (1998)

Santamäki, T.: Implications of the non-homogeneity of the standard and overtime hours on the structure and cyclical adjustment of labor input. In: Hart, R.A. (ed.) Employment, Unemployment and Labor Utilization, pp. 90-106. Unwin Hyman, Boston (1988)
Sargent, T.J.: Estimation of dynamic labor demand schedules under rational expectations. J. Polit. Econ. 86(6), 1009-1044 (1978)

Sargent, T.J.: In: Macroeconomic Theory, 2nd edn. Bingley, Emerald (2010)

Schiantarelli, F., Sembenelli, A.: Asymmetric adjustment costs and the estimation of Euler equations for employment: an application to U.K. panel data. In: van Ours, J.C., Pfann, G.A., Ridder, G. (eds.) Labor Demand and Equilibrium Wage Formation, pp. 149-161. North-Holland, Amsterdam (1993)

Schramm, F., Endemann, A.: Der deutsche Kündigungsschutz die Perspektive der Personalverantwortlichen. Wirtschaftsdienst 90(11), 735-741 (2010)

Shapiro, M.D.: The dynamic demand for capital and labor. Q. J. Econ. 101(3), 513-542 (1986)

Spermann, A.: The new role of temporary agency work in Germany. IZA Discussion Paper No. 6180, Institute for the Study of Labor, Bonn (2011)

Varejão, J., Portugal, P.: Employment dynamics and the structure of labor adjustment costs. J. Labor Econ. 25(1), 137-165 (2007a)

Varejão, J., Portugal, P.: Spatial and temporal aggregation in the estimation of labor demand functions. IZA Discussion Paper No. 2701, Institute for the Study of Labor, Bonn (2007b)

Vermeulen, P.: Employment stickiness in small manufacturing firms. Working Paper Series No. 640, European Central Bank, Frankfurt/Main (2006)

Windmeijer, F.: A finite sample correction for the variance of linear efficient two-step GMM estimators. J. Econom. 126(1), 25-51 (2005)

Wooldridge, J.M.: Econometric Analysis of Cross Section and Panel Data, 2nd edn. MIT Press, Cambridge (2010)

Yaman, F.: The costs of adjusting labor: evidence from temporally disaggregated data, Discussion Paper Series No. 11/10, Department of Economics, City University London, London (2011)

Sven Jung studied international economics at the University of Erlangen-Nuremberg. Since 2008 he is researcher and Ph.D. student at the Chair of Labour and Regional Economics at the University of Erlangen-Nuremberg. His research focuses on empirical labour economics. 